\title{
Encountering Tourism
}

Valerio Simoni

Subject: Sociocultural Anthropology Online Publication Date: Jul 2020

DOI: $10.1093 /$ acrefore/9780190854584.013.170

\section{Abstract and Keywords}

Tourism affects the lives of an increasing number of people across the world and has been growing and diversifying immensely since the turn of the $21^{\text {st }}$ century. Anthropological approaches to tourism have also expanded from the early contributions of the 1970s, which tended to focus on the nature of tourism and its "impact" on peripheral host communities. These first interventions see anthropologists theorizing tourism as a "secular ritual," studying its workings as a process of "acculturation," and countering macroeconomic views of tourism's potential for the economic development of peripheral societies by underscoring instead its neocolonial and imperialist features. Tourism is linked to the exacerbation of center-periphery dependencies, seen as an agent of cultural commoditization and responsible for the promotion and dissemination of stereotypical images of people and places. Moving beyond the impact paradigm, which has the disadvantage of portraying tourism as an external, disembedded, and imposed force on a passive population, constructivist approaches highlight its creative appropriations and integral role in the reinvention of culture and traditions. Anthropologists pay attention to the varied range of actors and agencies involved in tourism, accounting for the multi-scalar dimensions of this phenomenon and the uneven circulation of images, discourses, and resources it engenders.

Tourism exerts a powerful global influence on how alterity and difference are framed and understood in the contemporary world and contributes to the valorization and dissemination of particular views of culture, identity, and heritage. Tourism is increasingly intertwined with processes of heritage-making, whose study helps advance anthropological reflections on cultural property, material culture, and the memorialization of the past. A key source of livelihood for a growing number of people worldwide, tourism is also becoming more and more associated with development projects in which applied anthropologists are also enrolled as experts and consultants. The study of the tourism-development nexus continues to be a key area of theoretical innovation and has helped advance anthropological debates on North-South relations, dominant responses to poverty and inequality, and their entanglements with neoliberal forms of governance.

Given its diffuse and distributed character, tourism and touristification have been approached as forms of ordering that affect and restructure an ever-growing range of entities, and whose effects are increasingly difficult to tease out from concomitant societal 


\section{Encountering Tourism}

processes. The ubiquitous implementations of tourism policies and projects, the influx of tourists, and the debates, reactions, and resistances these generate underscore, however, the importance of uncovering the ways tourism and its effects are being concretely identified, invoked, acted upon, and confronted by its various protagonists. Research on tourism has the potential to contribute to disciplinary debates on many key areas and notions of concern for anthropology. Culture, ethnicity, identity, alterity, heritage, mobility, labor, commerce, hospitality, intimacy, development, and the environment are among the notions and domains increasingly affected and transformed by tourism. The study of tourism helps understand how such transformations occur, uncovering their features and orientations, while also shedding light on the societal struggles that are at stake in them. The analysis of past and current research shows the scope of the theoretical and methodological debates and of the realms of intervention to which anthropological scholarship on tourism can contribute. .

Keywords: anthropology of tourism, development, cultural commoditization, authenticity, stereotypes, heritagemaking, borderzones, touristification, globalization

\section{Introduction}

Tourism has become a global phenomenon affecting the lives of an increasing number of people across the world. Its modern beginnings are commonly located in mid-20th-century industrial-era Europe and linked to significant developments such as advances in transportation, the availability of free time and paid holidays, the preference for discretionary expenditure in travel, and the creation of a desire for sightseeing, to which also contributed the movement of Romanticism that preceded the advent of mass tourism. ${ }^{1}$ According to the World Tourism Organization's (UNWTO) Tourism Highlights (2018), tourism is linked to one out of ten jobs in the world, with the total number of tourism receipts estimated at 1.340 billion USD and international tourist arrivals at over 1.326 million people. There is no doubt that tourism is something with which anthropologists increasingly have to contend, and that tourism-related situations and events may have some bearing even in those field sites anthropologists could least image they would.

A multifaceted and highly diversified field, the study of tourism has enabled anthropologists to address both long-standing and new debates within the discipline. Tourism in the early 21st century is at the center of a broad range of anthropological research. In the past five decades, since the 1970s, issues of power, ritual, inequality, and exchange in North-South relations have been particularly salient in anthropological work on tourism, leading scholars to integrate multiple scales of analysis and move beyond clear-cut divides between the local and the global. Among the most established contributions, anthropologists working on tourism have helped advance disciplinary debates on identity, ethnicity, commoditization, and development. While paying attention to the nature of tourist experiences and relations, including the methodological challenges emerging from the potential similarities between tourists and anthropologists, research has more often 


\section{Encountering Tourism}

focused on tourism's effects among "host communities" and on the processes of social, cultural, economic, and political change that tourism fosters and is entangled with.

The anthropological study of tourism explicitly emerged over five decades ago, and thematic foci and approaches have diversified immensely since these early interventions. This also contributes to explain the impossibility of subsuming such study under one single and unified theoretical framework. There are a growing number of excellent summaries of the field's key areas on which anthropologists have tended to concentrate, and the impressive review of Leite and Graburn (2009) is tellingly titled "Anthropological Interventions in the Study of Tourism," in recognition to their finding "little evidence of a coherent subdiscipline" that could be called "the Anthropology of Tourism" $(2009,35)$. It is widely agreed that anthropological attention to tourism first arose in anglophone academia in the West, mainly in the United States. However, numerous edited collections and review articles have appeared in many countries and languages, especially since the beginning of the 21st century, making the disciplinary engagement with this phenomenon a truly global scientific endeavor, with transnational dialogues taking place as well as debates on national and regional research traditions. ${ }^{2}$ Rather than engaging in a comprehensive summary, this article focuses on the main approaches that have characterized anthropological encounters with tourism and constitutes a selective, analytical review of the anthropological study of tourism. The author attempts here to probe further certain key axes of investigation, drawing on them to illustrate how anthropological studies of tourism have transformed in the past five decades, up to their current state of proliferation in the year 2020.

\section{Early Foci and Approaches: The Tourist, Tourism, and "Impact"}

\section{Anthropologists' (Late) Encounters with Tourism}

The subject of tourism is a relative latecomer in anthropological research. Several interrelated explanations have been advanced for this, showing that tourism was for a long time seen as an improper subject "within the traditional purview of the discipline" (Nuñez 1977 , 208). Some of the main reasons for anthropologists' late encounter with tourism are rooted in the themes and approaches that tended to prevail when anthropologists started exploring this phenomenon. For one, as Crick (1989) puts it in his insightful review of representations of tourism in the social sciences, scholars may consider that “[a]nthropologists with a possessiveness about 'their' people and an oversimplified idea of traditional culture look askance at social change and the hordes of Western intruders 'queering their pitch'” (1989, 311-312; see also Boissevain 1977). As elaborated by Cousin and Apchain $(2016,4)$, tourists could be seen as ethnographers' followers, ugly reflections of the former coming to "contaminate" their pristine field sites, representing a "deformed mirror" to the anthropologist (see also Errington and Gewertz 1989), or travel's "idiots," as Urbain put it (1991). According to these authors, it is precisely the 


\section{Encountering Tourism}

proximity, rather than the distance, between ethnographers and tourists that hampered a fuller recognition of tourism as a legitimate object of serious anthropological scrutiny. If Lévi-Strauss introduced his famous Tristes Tropiques (1955) stating that he hated travels and travelers, thus marking the superiority of his scientific endeavors, two decades later Dumont provocatively argued that MacCannell's book, The Tourist: A New Theory of the Leisure Class-considered one of the first major theorizations of modern tourism-"ought to be frightening to anthropologists" $(1977,225)$ precisely for the similarities it uncovered between them and tourists. ${ }^{3}$

In their review of anthropological interventions in the study of tourism, Leite and Graburn (2009) recognize anthropologists' intentional omission of tourists' presence in their field sites before dividing anthropologists' early incursions into tourism research into four basic types: "empirical discovery, work on adjacent topics, theoretical extension, and critical analysis" $(2009,39)$. Empirical discovery evokes the study of tourism once it unexpectedly appeared at the ethnographers' field site, as in the path-breaking study of weekendismo in a Mexican village undertaken by Nuñez (1963), widely recognized as the first anthropological analysis explicitly focusing on tourism (but see Nogués-Pedregal 2019, on Redfield 1941). Graburn's early work on "airport art" (1967) is cited as an example of scholarship linked to tourism and later recognized as contributing to the anthropology of tourism, especially in terms of understandings of art, touristically induced cultural change, and representations of identity. In turn, an example of theoretical extension would be how concerns with traditional anthropological notions such as "ritual" (Graburn 1977, 1983B; MacCannell 1976; Turner and Turner 1978) or "acculturation" (Nuñez 1963; Smith 1977A) led scholars to devote analytical attention to tourism. With critical analysis came the recognition of tourism's imperialist and neocolonial effects on "peripheral" societies (Finney and Watson 1975; Nash 1977) and its negative consequences in terms of cultural commoditization and degradation (Greenwood 1972, 1977). In what follows, this article considers two main axes of concerns that directly followed from these early interventions, and which, as several authors have noted (see Graburn 1983B; Michaud 2001; Stronza 2001), have exerted a long-standing influence in framing and shaping anthropological research and debates on tourism: the study of the tourist and the nature of tourism, on the one hand, and the study of tourism's "impact" on host societies, on the other.

\section{The Tourist and the Nature of Tourism}

Anthropological interest in tourists and the nature of tourism (Graburn 1983B) stemmed mainly as a "theoretical extension" (Leite and Graburn 2009, 39) of engagements with more "classic" themes and concepts, such as ritual, pilgrimage, and modernity. As stated by Stronza (2001) and Michaud (2001), early 1970s-era anthropological focus on tourism tended to be more theory driven and deductive than empirically grounded and to rely on the assumed sociocultural proximity of tourists and the scholars that were generalizing about them (Michaud 2001). Early working definitions of the tourist often referred to the formulation of Smith (1977B), in her introduction to Hosts and Guests, in which she characterized the tourist as "a temporarily leisured person who voluntarily visits a place away

Page 4 of 52

PRINTED FROM the OXFORD RESEARCH ENCYCLOPEDIA, ANTHROPOLOGY (oxfordre.com/anthropology). (c) Oxford University Press USA, 2020. All Rights Reserved. Personal use only; commercial use is strictly prohibited (for details see Privacy Policy and Legal Notice). 


\section{Encountering Tourism}

from home for the purpose of experiencing a change" (1977b, 2). Since early on, however, starting with a foundational chapter by Graburn in that same publication, reflections on the nature of tourism and tourists relied on more sophisticated theoretical approaches inspired by anthropologists' long-standing engagements with notions of ritual (Stasch 2017, 3-4).

Combining Durkheim's (1912) reflections on the sacred with Leach's (1961) considerations on time and its important alternations and discontinuities, Graburn $(1977,1983 B)$ developed a theory of tourism as "secular ritual" and "sacred journey." Tourism is thus cast as a highly significant moment of ritualistic inversions and non-ordinary experience in people's lives, contrasted to the more "dull" and profane moments of work, and responding to a fundamental human need for recreation and renewal, of which Graburn provides compelling historical and contemporary examples. At about the same time, tourism also appears in the work of Turner and Turner (1978) in close association with the analysis of pilgrimage, which they observe shares the quality of liminality, the unstructured time that characterizes the middle stage of rites de passage in which people are lifted out of, and find escape from, the ordinary structures characterizing everyday life. ${ }^{4}$ Sharing, with Graburn's and Turner and Turner's theoretical interventions, the drive to rehabilitate the significance of tourism and of the tourist-in contrast to the more "herd-like vacuous amorality" (Graburn 2017, 85) ascribed to tourists by earlier commentators (see Boorstin 1964 or Turner and Ash 1975)—is the work of MacCannell (1973, 1976).

For MacCannell, who skillfully blends Marxism, semiology, French structuralism, and symbolic interactionism in his analysis, the tourist constitutes an ideal window to reflect and theorize about key features of modern society. Among such features is the typical alienation, instability, and fragmentation resulting from industrialization and modernization, leading to a loss of meaning and a sense of inauthenticity in social life. Tourism is a productive response to such an alienating context and serves as a unifying force, bringing together people in their quest for and recognition of "authentic" places and experiences. MacCannell's modern urban middle classes are said to seek authenticity by traveling elsewhere and visiting tourist attractions. The added subtlety and paradox in MacCannell's theorization is that the tourism industry, eager to capitalize on the tourists' desires, is responsible for "staging" authenticity. This makes tourists increasingly suspicious of "fake" tourist displays, leaving them eternally unsatisfied and constantly seeking new grounds to satisfy their quest for the "real" and the authentic. The publication of The Tourist constituted a major landmark for social science work on tourism, leading Graburn (2017) to recognize, in his recent anthropological reassessments of the notion of the tourist, that "much of the social science of tourism in the subsequent decades has been in reaction to and modification of MacCannell's ideas" (Graburn 2017, 85, see also the section "MULTIPLYING 'THE TOURIST'”). 


\section{Encountering Tourism}

\section{The “Impact" of Tourism on Host Societies}

Alongside the study of tourists and the nature of tourism, the other major realm of anthropological research on tourism rose out of concerns with the issues of change and development. Such concerns delineated the key themes that would occupy anthropologists for the following decades, centering on the study of economic and sociocultural change (Crick 1989; Stronza 2001), or what was often referred to as the "impact" of tourism on host societies. In contrast to scholarly reflections on the nature of tourism and tourists, where generalizing theories predominated, Stronza (2001) observes that in studies of impact researchers relied much more on data than on theory. Accordingly, a proliferation of case studies appeared alternatively illustrating the "positive" or "negative" consequences of tourism, with negative assessments prevailing (Crick 1989). Many social scientists in the 1970s took it as their task to criticize the prevalent economistic view of tourism as a panacea for development, which had been pushed by economists and was endorsed by international organizations such as the United Nations and the World Bank from the early 1960s (see Turner and Ash 1975; de Kadt 1979; Michaud 2001). Reacting to reductive views of macroeconomic development and criticizing their simplistic and quantitative approaches, anthropologists warned of the risks and dangers of tourism for host societies, pointing to dependency, raising inequalities, and failed wealth redistribution, underscoring tourism's insertion into long-standing patterns of North-South exploitation and giving currency to a view of international tourism development as a form of imperialism and neocolonialism (Nash 1977; Crick 1989).

Initiating a long tradition of anthropological research on the impacts of tourism on host communities, Nuñez's (1963) seminal article on weekendismo in a Mexican village saw tourism as a kind of "laboratory situation" for testing "acculturation theory" (Redfield, Linton, and Herskovits 1936). Nuñez's study demonstrated both negative and positive consequences of tourism, providing compelling evidence that tourism was bringing rapid and dramatic changes to a host society in terms of, for instance, its sources of authority and power relations, land-use patterns, value systems, and economic functioning. The acculturation approach inspired subsequent theorizations on tourism's impact, including Nash's (1977) view of tourism as a form of imperialism, and can be juxtaposed to another influential early assessment of tourism's consequences on a peripheral population, that of Greenwood $(1972,1977)$ on tourism as an agent of change and driver of cultural commoditization. Greenwood's (1977) early assessment, a retrospectively self-declared exemplar of anthropological critiques of modernization (Greenwood 1989), was more trenchant and critical of tourism than Nuñez's earlier intervention and became widely cited for pinpointing the destructive process by which culture-exemplified in his case by a public ritual, the Alarde, commemorating a military victory in a Basque town in Spain-became commoditized and lost its original meaning once it was sold as a spectacle to tourists.

But not all these early analyses of the sociocultural impacts of tourism followed Greenwood's moral outrage and pessimistic assessment. Another chapter in Smith's (1977A) Hosts and Guests saw McKean build on Geertz's (1963) reflections on processes of "involution" to propose the notion of "cultural involution" in Bali, and suggested that 


\section{Encountering Tourism}

"tourism may selectively strengthen local traditions and societies" (McKean 1977, 107) by infusing certain cultural expressions and occupations (e.g., as carvers, musicians, dancers) with new vitality while satisfying tourists' expectations. In this case, tourists become patrons and sponsors for specific ethnic and cultural manifestations, outlining a picture that "contrasts with the assertion by both anthropologists and tourists that culture is a static entity, self-contained and isolated, that will wither like a fragile flower when exposed to chilling exterior influences" (McKean 1977, 104). In a similar vein, Smith (1982) showed how in Greenland tourism seemed to reinforce "ethnic identity," a view further elaborated in Keyes and van den Berghe's (1984) pioneering special issue of Annals of Tourism Research, exploring tourism as "ethnic relation." As indicated by McKean's quote, much of the assessment of tourism's cultural impact on host communities, and the attribution of a "positive" or "negative" valence to it, could ultimately depend on anthropologists' approaches to culture and cultural change.

\section{Critique and Consolidation: Complexifying Agencies and Effects of Tourism}

\section{Multiplying "The Tourist"}

The earliest and most forceful critique to the generalizing reflections on "the tourist" and the nature of tourism, as theorized most notably by MacCannell (1976), came from the work of Cohen (1979) and his "phenomenology of tourism experiences" in which the author called for the recognition of a variety of tourists' attitudinal postures, urging scholars to move beyond a unified view of tourism motivation. A fundamental and convincing element of Cohen's critique was to consider that tourists are in themselves a very diverse population, driven by different motives and desires. Therefore, one cannot assume that they are all middle-class alienated individuals seeking authenticity, as MacCannell (1976) suggested, or that everyone's vacation constitutes a sacred journey (Graburn 1977). What about all those people who seemed to go on holiday just for idle pleasure? Cohen calls for more empirically grounded, inductive theorizing offering a classification of tourist "modes" based on tourists' diverse motivations. He distinguishes these modes based on travelers' curiosity to seek out new experiences, at one end of the spectrum, and the need for the security of the familiar at the other. Proposing a continuum of "recreational," "diversionary," "experiential," "experimental," and "existential” modes, Cohen's sophisticated typology enabled accounting for an ample range of tourist experiences.

If Cohen's classification and those of other qualitative social scientists in the 1970s (see Smith 1977B) proved helpful in diversifying and complexifying the picture of the tourist's motivations, Bruner's (2001) trenchant critique observed that "typologies of tourism and tourists ordered the data" but ultimately "yielded few insights" (881). While building on the pioneering work of MacCannell, Graburn, and Cohen, anthropological work on tourists has moved away from sweeping generalizations and typological classifications, shifting to more empirically grounded, contextually situated explorations of tourist prac-

Page 7 of 52

PRINTED FROM the OXFORD RESEARCH ENCYCLOPEDIA, ANTHROPOLOGY (oxfordre.com/anthropology). (c) Oxford University Press USA, 2020. All Rights Reserved. Personal use only; commercial use is strictly prohibited (for details see Privacy Policy and Legal Notice). 


\section{Encountering Tourism}

tices and experiences. Particularly since the late 1990s, there has been a range of edited collections and monographs based on ethnographic case studies subtly addressing a diverse array of tourist practices and experiences. ${ }^{5}$ This scholarship has helped take research on tourism and tourists toward exciting new directions, providing new analytical insights on the practice of tourism as a situated, reflexive, embodied experience in which lines of differentiation related to class, gender, race, ethnicity, origin, and positionality are also foregrounded (see Graburn 2017).

The growing heterogeneity and diversification of tourism is reflected in the number of publications devoted to analyzing emerging forms, modalities, and "niches" of contemporary travel that pertain to or at least partly intersect with tourism. These bring forward and complexify earlier typologies of tourism of the 1970s (see, e.g., Smith 1977B, and her classification of "ethnic," "cultural," "historical," "environmental," and "recreational" tourism) and also broaden the scope of analysis beyond research and classification of "alternative" forms of tourism that took force in the 1990s (e.g., the labels "eco," "sustainable," "community-based"; see, e.g., Smith and Eadington 1992; Stronza 2001; and this article, "APPLIED INTERVENTIONS"). Thus, there are edited volumes and special issues focusing on forms of travel and tourism qualified as "dark" (Sharpley and Stone 2009; Skinner 2012; White and Frew 2013), "diaspora" (Coles and Timothy 2004; Marschall 2017), "medical" and "reproductive" (Naraindas and Bastos 2015; Inhorn 2015; Nahman 2016; Speier 2016), "primitivist" (Stasch 2015), or "volunteer" (Benson 2011; Vastri 2013; Mostafanezhad 2014), just to mention some significant examples. This scholarship sheds new light on the ways tourism informs and is, in turn, being reshaped by concomitant trends and changes in realms as diverse as medicine, development, heritage, and, more transversally, in the ways alterity, difference, and unequal North-South relations are being represented and acted upon in the contemporary world. The desire to provide anthropological accounts that remain close to the tourists' lived practices, experiences, and subjectivities have also led scholars to reflect on the challenges of doing ethnographies of tourists (Graburn 2002; Bruner 2005; Frohlick and Harrison 2008A; Simoni and McCabe 2008; Mancinelli 2008; Andrews, Jimura, and Dixon 2019), moving subjects that anthropologists may find it difficult to follow and spend time with. Such contributions nourish broader methodological debates on how to do research on mobile populations (see Elliott, Norum, and Salazar 2017). Reflections on tourism and tourist practice thus feed into and benefit from more encompassing theoretical and methodological conceptualizations of "mobility" and "mobility regimes" (Cresswell 2006; Sheller and Urry 2006; Hannam, Sheller, and Urry 2006; Urry 2007; Salazar and Smart 2011; Glick Shiller and Salazar 2013; Cohen and Cohen 2015; Salazar and Jayaram 2016; Salazar and Coates 2017; Salazar 2018). At stake are the intersections and (dis)continuities between tourism and other forms of travel, including privileged modalities of migration (see, e.g., Amit 2007; D'Andrea 2007; Benson and O'Reilly 2009; Norum 2013). A telling illustration of the increasingly blurred frontiers of tourist practices, and of tourism's entanglements with other domains of life and praxis that confound established distinctions between work, leisure, and travel, can be found in scholarship on neo and digital nomadism (D'Andrea 2007; Mancinelli 2018; Thompson 2019), or in Loloum's (2018) critical analysis of profes- 


\section{Encountering Tourism}

sionals "making a living out of travel and leisure." Here is where research on tourism may also contribute to broader anthropological reflections on changes in (increasingly precarious and flexible) work and labor regimes that are both conducive of, and in turn shaped by, such transformations. Theoretical and methodological reflections on tourism that reposition it within a broader field of contemporary practices and ideologies of discretionary travel and mobility can thus help researchers better understand its specificities as well as its (blurred) frontiers and disseminations (see also, this article, "BROADENING THE VIEW, EXPANDING THE CONTRIBUTION," and “CONCLUSION”).

The multiplication and diversification of tourism practices, as well as its convergences and overlaps with other practices of privileged travel, also mean that finding a clear-cut and universal definition of the tourist has become increasingly difficult, if not hopeless, and perhaps also unproductive. Frohlick and Harrison tellingly urge scholars to not 'quibble over the semantics of 'tourist' as a definitional term but rather use ethnography as a productive means to ascertain specific, locally situated and often contested meanings of 'tourist' as well as the everyday means through which touristic travel is part of people's identity constructions" (Frohlick and Harrison 2008B, 12). Attention is thus brought to the relational (Abram and Waldren 1997), performed (Edensor 1998), purposeful (McCabe 2005), embodied (Leite 2005), and locally situated (Hom Cary 2004; Frohlick and Harrison 2008B; Simoni and McCabe 2008) nature of tourism-related roles and positionings. This way, scholars may also uncover "what people achieve by deploying concepts like 'tourist' in their constructions of themselves and the activities of others" (McCabe 2005, 100). What has to be foregrounded here, following Cousin and Apchain's $(2016,11)$ consideration of anthropology's distinctive contribution to the study of tourism, is the adoption of an empirically grounded, inductive methodological posture whereby the issue is not so much to define a priori who is a tourist or to suppose what drives the practice of tourism. Instead, anthropologists are ideally placed to contextually explore questions such as the following: When is one a tourist, and who comes to count as such? Who is ascribing, endorsing, and assuming this designation and how? What does this identification, and the experience of it, evoke, entail, enable, and constrain? How is being a tourist differently and commonly enacted and performed? What does this tell us about the way tourism, among other forms of mobility, operates in the contemporary world, from the specificities of particular practices and destinations to its more globalizing dimensions?

\section{Unpacking “Hosts," Revisiting “Impacts," and Creating (Tourism) Culture}

\section{Tourism as a Complex System}

While evocatively foregrounding the key areas of anthropological focus on (a) tourists and (b) members of a visited population, the "hosts and guests" dyad progressively came under the increasing criticism of anthropologists, particularly in the 1990s. As Selwyn (1994) put it, these notions prove ultimately "too simple in a complex world in which 'hosts' no longer meet 'guests' in some latter day Maussian paradigm” (730). Tourism in- 


\section{Encountering Tourism}

volves a broad range of actors and agencies that cannot be contained in such binary formulation, which has the additional disadvantage of disguising the commercial aspects that are also at the center of this service sector (Aramberri 2001). Moving beyond hosts and guests, tourism is increasingly recognized as a multifaceted assemblage of objects, infrastructures, imaginaries, and people, and the call is for anthropologists to account for such plurality of actors and agencies as well as their interrelations.

As early as 1980, in his conceptualization of tourism as a form of ethnic relations, van den Berghe recommended broadening the range of protagonists to recognize the importance of "middlemen" in tourism. Middlemen are akin to the "cultural brokers" previously considered by Smith (1977C) and Nuñez (1977), people who develop skills and engage in entrepreneurial activities specifically tailored to tourists. Under this categorization, and drawing on a case study of Cusco (Peru), van den Berghe regroups "travel agents, airline employees, taxi drivers, hotels and restaurant managers, guides, curio shop vendors, and so on" $(1980,381)$, bringing attention to the ways in which these categories intersect with ethnicity and class. The recognition of such tourism professionals and of their crucial role in mediating encounters in the tourism realm has received renewed attention in recent years and has helped open up the range of tourism protagonists who are ripe for anthropological analysis. ${ }^{6}$ Moving a step further still, Selwyn's (1994) delineation of the field of the anthropology of tourism broadens the space of anthropological inquiry to an even greater variety of actors, including (a) tourists and (b) people living in tourist destinations, but also (c) academic "participant observers" (e.g., social scientists, museum curators, historians), (d) the tourism industry, (e) government and non-governmental organizations, and (f) international agencies such as the UN or the World Bank. Research on the three latter dimensions has lagged behind in the anthropology of tourism, as observed by Cousin and Apchain (2016), who bemoan the lack of empirically grounded analysis of the tourism industry (from accommodation to travel agents and transport) and international organizations (13), research areas more commonly addressed by tourism management scholars. ${ }^{7}$ The pioneering work of Lanfant (1980; Lanfant, Allcock, and Bruner 1995) and her research team in Paris (URESTI-CNRS) constitutes a notable exception, as it approached tourism within internationalization processes, entangling it in broader dynamics of social change and globalization and integrating different scales of analysis.

The lasting lesson is that even micro-level investigations of tourism's impact on smallscale host communities need to take into account the broader, multi-scalar network of power relationships, discourses, and representations in which actors and localities are enmeshed (Kahn 2000; Favero 2003; Neveling and Wergin 2009; Cousin and Martineau 2009; Regi 2014; Jacobsen 2018). Exemplifying the development of such multi-scalar approaches, scholars can consider an important body of anthropological work on the constitutions of tourism-related images and stereotypes of a "destination." Pi-Sunyer's (1977) early emphasis on the preexisting stereotypes shaping tourism relationships is thus brought a step further in Adams' (1984) work on how travel agents and tourism brochures frame Torajan ethnicity and culture in Indonesia, in Picard's $(1992,1996)$ research in Bali on the interrelations between the Indonesian state's promotion of the island and local responses to tourism policies, and in scholarship linking the state, policy- 


\section{Encountering Tourism}

making, and ethnicity in tourism (Picard and Wood 1997). The analysis of the constitution of particular "ways of seeing" and the (global) circulation of (stereotypical) images of "destinations" and its people (Adams 1984; Urry 1990; Selwyn 1993, 1996) has been recently revitalized by a focus on master narratives (Bruner 2005), tourism worldmaking (Hollinshead, Ateljevic, and Ali 2009; Hollinshead and Suleman 2018), tourist anticipation (Skinner and Theodossopoulous 2011), and tourism imaginaries (Salazar 2010, 2012; Salazar and Graburn 2014; Gravari-Barbas and Graburn 2016), which helps unpack the global traffic of images and fantasies of people and places that tourism fosters, its origins and channels, as well as its power differentials and concrete effects. ${ }^{8}$

\section{Beyond Impact: Revisiting Power and Agency}

The impact language and approach to tourism has been convincingly criticized, particularly from the 1990s onward, for simplistically portraying local populations as fragile, cohesive entities and passive recipients of tourism (Leite and Graburn 2009). Countering such assessments and answering the early criticisms of authors such as Wood, who in 1980 had already shown how views of tourism "spoiling" cultures betrayed "a Western ethnocentrism and romanticism in their desire to 'preserve' cultures" (Wood 1980, 564), a new wave of studies emphasized local people's agency and active involvement in tourism.

Even the poorest and most marginalized populations were thus seen not to be passive targets but to have agency and to act tactically and strategically to make the most of tourism. One of the most forceful critiques of the notion of impact was articulated by Picard (1979), for whom "the mere fact of talking about the 'impact' of tourism entailed something of a ballistic vision, that led to perceiving the so-called host society as a target struck by a projectile, like an inert object passively subjected to external factors of change, which experts were expected to assess by means of a cost-benefit analysis, involving some sort of trade-off between cultural and economic values" $(2007,173)$.

With his long-term anthropological work in Bali, Picard $(1992,1996)$ rendered the prevailing view that tourism had contributed to the preservation and regeneration of traditional cultural heritage on the island far more nuanced, doing so by collapsing a series of taken for granted oppositions between "inside" (local society) and "outside" (international tourism) and between "cultural" and "economic" values (Picard 2007, 173.). Adopting a constructivist and dynamic approach to culture, Picard shifted the typical question of investigating how the Balinese withstood the impact of tourism to understanding instead "how tourism has contributed to the advent of the very notion of a 'Balinese culture'" $(2007,173)$, with the Balinese ultimately "taking the brand image of their tourist product for the marker of their cultural identity" $(2007,173)$. What seemed significant in such a process of "touristification" was the growing self-consciousness, appropriation, and valorization of an anthropologically outdated vision of culture, as a "substance with precisely defined characteristics" (Picard 2007, 177), and this at a time in which anthropologists forcefully called for more dynamic conceptions of this notion (see Linnekin 1983; Handler and Linnekin 1984; Hobsbawm and Ranger 1983; Handler 1988; Clifford 1988; Keesing 1989), if not openly “writing against culture” (Abu-Lughod 1991). 


\section{Encountering Tourism}

Picard's view resonates with other anthropological analyses of tourism, particularly in the 1990s, which revisited the notion of impact to highlight instead how people in tourist destinations selectively appropriated tourism and related notions of culture, often in concert with anthropological discourses and political and economic actors at the regional, national, and international level (see Castañeda 1996). Analyses could then focus on the dynamics of such appropriation, uncovering its power dimensions and lines of differentiation, and therefore overcoming any simplistic view of a unified, organic, and cohesive "host community." Swain (1977) had already shown the importance of gender in shaping participation in tourism, marking an important step toward what Stronza (2001) sees as the key question of understanding "why and under what conditions local residents may choose to, or may be driven to, become involved in tourism" (267). ${ }^{9}$ In her work among the Toraja, Adams $(1993,1995)$ has made important advances in uncovering Torajans' skillful and strategic manipulation of tourism for economic and political ends, including calling upon anthropologists to "authenticate" particular versions of local heritage and culture (Adams 1993, 1995, 2005, 2006; see also MacCarthy 2016). An abundant body of subsequent scholarship has highlighted the agency, relative power, and diversity of entanglement in tourism, helping scholars move beyond a static "local-victim"-“tourist-oppressor" dualism. ${ }^{10}$ Such recognition of multiple vectors of power and agency would ideally be accompanied by identification of the precise shape that power and agency take in touristic encounters, and what these formations say about the epistemological, moral, and political issues at stake (Simoni 2018).

\section{“Borderzones” and the Creation of (Tourism) Culture}

Picard's $(1992,1996,2007)$ reflections on "touristic culture" also helped shed new light on the related issue of authenticity, a key axis of interest in anthropological interventions on tourism, at least since MacCannell (1976). Following his earlier condemnation of tourism as an agent of cultural commoditization, Greenwood (1982) recanted and argued that all cultures "are in the process of making themselves up at all times" and that in this sense "all culture is 'staged authenticity'" $(1982,27)$. This dynamic, processual, constructivist stance toward culture and authenticity, which revisits the opposition between authenticity and commoditization, is strongly supported by the work of Cohen (1988), Bendix (1989), and Adams (1995), showing that conscious reformulations of rituals, history, and culture, and the intervention of money in the process, do not necessarily imply a loss of meaning, authenticity, or emotional power (see also Bunten 2008, 2015). Rather than bemoaning a lost authenticity that only the anthropologists supposedly can recognize, tourism's valorization of alterity, culture, and difference (Meisch 2002; Salazar 2005, Cousin 2008, Cousin and Apchain 2016; Palou Rubio and Mancinelli 2018B) and the way processes of touristification contribute to actualize, tame, format, and reshape national, cultural, or ethnic difference in specific ways is what merits anthropological attention. ${ }^{11}$ As Greenwood $(1989,183)$ put it, "being culturally authentic" may represent a way of accessing recognition and resources otherwise difficult to achieve, following a pattern that is increasingly at play as well in the field of indigenous claims and struggles (see Hodg- 


\section{Encountering Tourism}

son 2002; Sylvain 2005; Comaroff and Comaroff 2009; Bunten and Graburn 2018; Jacobsen 2018).

The work of Bruner $(1994,2005)$ serves as an example of empirically grounded, theoretically sophisticated anthropological approaches to authenticity and the invention of culture in tourism. ${ }^{12}$ A key notion developed in his work is the "touristic borderzone," the "performative space within which tourists and locals meet" (Bruner 1999, 461), seen as "a creative space," "a site for the invention of culture on a massive scale," and one "that anthropology should investigate, not denigrate" (Bruner 1996, 159). The prevailing scripts, images, and metanarratives that come into play in borderzones are usually part of much larger "tourist tales" (Bruner and Kirshenblatt-Gimblett 1994, 467) with a history of their own, a history in which colonialism and domination tend to feature heavily. In the case of the Maasai performances Bruner studied in Kenya, for instance, colonialism had played a key role in shaping their global image as "male warriors." Bruner raises important questions about the extent of control that the Maasai have over the images by which they are represented and is led to suggest that they are by and large "willing to play into the stereotypical colonial image of themselves to please their clients, the foreign tourist" $(2001,896)$. Bruner reviews other examples from across the world of tourism's tendency to reify the specificity of the people living in a given destination $(2001,881)$. The author's own ethnographic work shows that Cuba is no exception to this global trend, with the stereotype of the "hot" Cuban being constantly re-actualized in a culturalist-nationalist vein in interactions with tourists, notably when trying to seduce and establish long-term relationships with them (Simoni 2013).

Tourists the author met in Cuba could get along happily with a Cuban's friendly call to join and spend some time together, knowing all the while that this was just part of "tourist time," a performance moment after which each partner would reintegrate in the communities to which they allegedly belonged, in "real life" (Bruner 2001, 67). Visitors could play "as if," maintaining a playful distance in a stance akin to that of the "posttourist" (Feifer 1985, 267; Urry 1990, 11), which sees acutely self-reflexive tourists play with normative scripts and roles. With no explicit agreement or common understanding of the frame in which relationships took place, what for tourists in Cuba could be "performance time," however, could be Cubans' "real life," delineating situations rife with possibilities for playing with power, ambiguity, and misunderstandings (Simoni 2012, 2014A, 2016A). As shown elsewhere (Simoni 2014B, 2016A, 2016B, 2018, 2019), Cuban men and women often strived to tease their intimate relationships with tourists out of the touristic borderzone and so also to reach beyond the overdetermined identifications of "tourist" and "Cubans." The framing of relationships with tourists along the idioms of "love" and "friendships" was an attempt to break down pre-established boundaries and typifications (e.g., Cuban-tourist, host-guest, us-them) and encourage tourists to commit to a relationship that would respect the integrity of the other, without reducing him or her to a (stereo)typical example of a more general category (see Simoni 2014B; Throop 2014; Leite 2017). 


\section{Encountering Tourism}

Besides anthropologists' long-standing focus on "the ideas that tourists carry with them and project onto what they see" (Stasch 2017, 5), Stasch's recent review similarly brings into focus the "effects fostered by spatial and social displacement itself" (Stasch 2017, 5), among which is the "creation of new social systems" (2017, 8-11; see also Picard and Di Giovine 2014). To what extent and how does movement between places break apart "existing forms of life and assembles fundamentally different ones?" (Stasch 2017, 7). Leite's (2017) insightful monograph on Portuguese descendants of 15th-century Jews forcibly converted to Catholicism, who seek lasting bonds with foreign Jewish tourists as a means of learning about their lost heritage as well as creating Jewish "kin" in the present, is highlighted by Stasch as exemplifying this attention to "tourism participants' mutual involvement," and "the new systems of ideas and social relations they create together" (Stasch 2017, 10-11). The generative potential of tourism to reformulate "relational idioms" and identifications is similarly at the center of the author's work on informal encounters in Cuba (Simoni 2016A). Starting from the early contribution of Cohen (1971), scholars have shown how, from within tourism, notions of friendship (Cohen 1971; Simoni 2014C; Buchberger 2014), reciprocity and hospitality (Adams 1992; Tucker 2003), love and partnership (Brennan 2004; Kummels 2005), kinship and the self (Leite 2017), and market and commerce (Forshee 1999; Causey 2003; Simoni 2009) are worked over, renegotiated, and reshaped. A growing corpus of research on the intimate relationships that tourism engenders-whose popular designations as "sex tourism" and "tourism prostitution" often fail to do justice given the thickness and complexity of discursive, material, and emotional transactions at play in these relationships - has also provided fresh insights into tourism's potential to profoundly alter people's lives, subjectivities, and worldviews. ${ }^{13}$ Beyond the view of tourism impacting or (in a reversal of agencies) being used by a local community-approaches that risk reinforcing simplistic equations between community, locality, nation, and allegiance (see Gupta and Ferguson 1992) - the relations that tourism generates merit attention in and of themselves, given that from within them important shifts can originate in people's identifications, aspirations, sense of belonging, and orientation to the world (Simoni 2016B, 2018; Leite 2017).

\section{Broadening the View, Expanding the Contribu- tion}

\section{Transnational Academic Dialogs}

Among recent attempts to open up the field and further highlight its relevance for addressing broader and timely anthropological issues is the call to diversify the epistemological foundations of the discipline by decentering and pluralizing knowledge beyond its classic centers of power in the United States, the United Kingdom, and France-part of a wider ongoing critique of anthropology's colonial and Euro-American hegemony entanglements. Introducing their edited volume on the rise of Asian tourism, Winter, Teo, and Chang (2009) convincingly illustrate the need to unpack a range of geographical and cultural biases permeating the field of tourism research, calling on scholars to challenge 


\section{Encountering Tourism}

"many of its assumptions and norms" $(2009,18)$ and move beyond the "Anglo-Western centrism" that tends to inform theoretical foci and approaches. Such decentering seems all the more important considering "that (historical) anthropological ideas have greatly influenced contemporary tourism" (Salazar 2017, 723). ${ }^{14}$ The theories and ideas of anthropologists inform the interpretative landscape of tourism, from international organizations, to guides and consultants, to the very tourists and members of the visited populations. In light of the growing body of scholarly production in a diversity of languages and valorizing localized intellectual genealogies, questions are being raised as to the extent and significance of epistemological differences based on the academic traditions and the regional and geopolitical positionalities from which scholars have approached tourism. These are among the questions addressed in a recent issue of the American Anthropologist's "World Anthropologies" section, which aimed at drawing attention to the study of tourism beyond the Anglo-American world, while also warning of the risks of "methodological nationalism" intrinsic in such an endeavor, which can lead to arbitrarily identifying and ascribing national traditions in scholarly productions that are increasingly transnational (Salazar 2017, 724).

Discussing Ibero-American anthropologies of tourism, Milano (2017) highlights Hernández -Ramírez, Pereiro Pérez, and Pinto's (2015) edited Overview of Anthropology of Tourism from the South as a key milestone for anthropological work on tourism, and more particularly, on the tourism-development nexus in Hispanophone and Lusophone academia (see also Palou Rubio's 2014 note on the anthropology of tourism in Spain, and Montero's 2018 critical review of studies of tourism in anthropology in Latin America and the Caribbean). In their article on the "domestication" of tourism anthropology in China, Zhu, Yin, and Graburn (2017) convincingly show how scholarly foci in this country, notably on ethnic tourism and cultural heritage, are implicated in "a plural hegemonic discourse of nation-building and modernization" (2017, 734). Drawing on Santos (2006) and Ribeiro Escobar (2006) to "approach Mexican anthropology of tourism as a product of situated knowledge," López Santillán (2017) illustrates the links between "touristification as a development project in Mexico" $(2017,725)$ and anthropological foci in this country, with the themes of dispossession, uneven development, heritage, and ethnicity being foregrounded as a result. Rather than responding to alluring calls of new scholarly trends and "turns," López Santillán thus makes the compelling argument that "[u]ndrevaluing the problem of development as a topic of research implies making an argument that comes from a hegemonic position, one that fails to recognize diversity in sociological and epistemological contexts, including the political economy of tourism" $(2017,728)$.

Commenting on these interventions, Habib (2017) raises the troubling question of "whether these truly are different conversations within anthropology concerning tourism or if they are simply reproducing recognizable debates from a series of different locales/ locations" (2017, 743-743). For Yamashita, instead of being "satisfied with 'the periphery' striking back at the hegemonic anthropology of the 'Western'-particularly US, UK, and French-centers" $(2017,746)$, the goal should be to move beyond national and regional differences "to enlarge the anthropological horizon (Restrepo and Escobar 2005)" (2017, 746) and achieve a global, world anthropology. Debates will no doubt continue in the com- 


\section{Encountering Tourism}

ing years on the strategies that could facilitate the establishment of more inclusive exchanges and collaborations and a movement toward greater recognition of the multiple, plurilingual contributions to the anthropological study of tourism from across the world. Reflexive awareness of how national institutional agendas, intellectual traditions, and hegemonic politics of publishing inform themes and approaches in the anthropological study of tourism, and can ultimately end up informing the very shapes taken by tourism in certain contexts, certainly merits staying at the center of scholarly attention.

\section{Applied Interventions}

In her reflections on the anthropological study of tourism in Mexico, López Santillán (2017) refers to applied, development-related anthropology as one of the key areas of research in the country, as do Zhu et al. (2017) in the case of China, where "tourism anthropology facilitates Chinese ethnic tourism on the ground by engaging with applied and development projects" $(2017,732)$. The linkage between tourism and development, as discussed in "The 'IMPACT' OF TOURISM ON HOST SOCIETIES," is a long-standing one. It is also in relation to development issues that anthropologists' applied interventions have mostly focused. Especially since the 1990s, Stronza (2001) indicates that "tourism has gained a much more positive reputation among social scientists, environmental conservationists, development practitioners, and indigenous rights activists" (274). This is notably due to the expansion in what came to be known as "alternative tourism" (Smith and Eadington 1992), whose various manifestations have been labeled as "ecotourism," "community-based tourism," "cultural tourism," "responsible tourism," "pro-poor tourism," "ethical tourism," "volunteer tourism," and so on (see Vivanco [2006] for a critical analysis). The emphasis given to respect for local culture and values, and the positive potential ascribed to tourism for "achieving a wide array of social, economic, and environmental goals" (Stronza 2001, 274), provided a favorable context for anthropologists to put their knowledge to the service of "planning and implementation of tourism projects around the world" (Stronza 2001, 275).

Following earlier publications on the potential of applied anthropological research in tourism (see, e.g., Chambers 1997B), a special issue of the NAPA Bulletin was published on Tourism and Applied Anthropologists (Wallace 2005), providing a timely overview of anthropologists' practical engagements in tourism as researchers, analysts, consultants, and advocates, as well as tour guides. From anthropologically informed advice on how to "become better tourists" (Chambers 2005), to reflections on the ethics of research in tourism situations in which the anthropologist is called upon to provide legitimized versions of heritage and culture (Adams 2005), to anthropologists-cum-consultants in tourism development projects struggling to redefine the terms of "community participation" (Wallace and Diamente 2005), to the anthropologist as cultural broker mediating the communication of diverging expectations among different ecotourism partners (Stronza 2005) - the cases presented in this special issue provide good examples of the roles and challenges of anthropologists' direct involvement in shaping tourism. 


\section{Encountering Tourism}

Addressing from a different angle the issue of an applied anthropology of tourism, and raising the more fundamental question of how to approach the notion of "intervention" in this field, Abram (2010) unpacks several important assumptions that often remain implicit in applied endeavors, including the "normative moralizing pressures" $(2010,248)$ placed on its practitioners. She thus uncovers the ethical, epistemological, and political dilemmas faced by anthropologists engaged in realms of tourism consultancy, noting that in the urge to "make anthropology relevant," too many questionable premises are often left untouched, key among them "the definition of tourism as a strategy for economic development," or "as an economic process with cultural 'effects' and 'impacts'” $(2010,237)$ -the view of tourism as an external and disembedded force that anthropological research on tourism has worked hard to dismantle. Abram's reflection calls for a rethinking of "what intervention is and how it might be imagined," and finds that a way of doing so is by interrogating the dichotomy between academic-pure and applied-useful knowledge, as done by anthropologists studying development practices (Long and Long 1992; Gardner and Lewis 1996). While creatively reimagining its meaning and scope, Abram also encourages anthropologists to extend anthropological interventions beyond the narrow channels of consultancy in development projects and "impact-related studies" and toward other key sites of power where tourism policy and planning are determined.

\section{Building Disciplinary Bridges, Diffusing Tourism}

In their reviews of the field, Leite and Graburn (2009) and Roberts and Andrews (2013) grapple with the slipperiness and challenge of writing about "the anthropology of tourism." While finding "little evidence of a coherent subdiscipline" (Leite and Graburn 2009, 35), Leite and Graburn recognize that what complicates any review of the subject is also "the overall trend toward interdisciplinarity in tourism research," and the fact that anthropologists "have long drawn upon sociology, geography, history, political science, critical theory, and cultural studies in making sense of their field materials" $(2009,35)$. Roberts and Andrews (2013) similarly acknowledge the increasing fuzziness of "tourism anthropology" as a sub-discipline, noting that tourism itself has become "ever more amorphous and multi-sited" (2013, 14-15), and choosing to focus their review "on the doing of tourism anthropology" $(2013,14)$. Confounding strict disciplinary boundaries, their article gives salience to issues of experience, embodiment, performance, affect, and the senses (Andrews 2011; see also Palmer and Andrews 2019), which have also shown much potential for refreshing anthropological takes on tourism in the studies by Ness (2016) and Little (2020).

The reflections of Leite and Graburn (2009) and Roberts and Andrews (2013) on disciplinary contours and entanglements speak to current developments in anthropological work on tourism, where, on the one hand, we see a proliferation of tourism social science conferences and publications, including anthropological contributions to a broader "tourism studies" field, while, on the other hand, we have anthropologists working on tourism-related phenomena that "seem unaware that an interdisciplinary tourism studies community exists" (Leite and Graburn 2009, 55). Within the interdisciplinary tourism studies community, the important role played by the International Academy for the Study of Tourism 


\section{Encountering Tourism}

must be noted.$^{15}$ Created in 1988, this institution brought together several funding scholars of the study of tourism in the social sciences. Since 2005, a network of Critical Tourism Studies (CTS) (Ateljevic, Pritchard, and Morgan 2007) has emerged to challenge dominant applied business-centered approaches of tourism. ${ }^{16}$ CTS has recently been assessed as embracing a "range of poststructuralist, neo-Marxist, critical realist, feminist, and postmodern approaches," including, among others, "actor-network theory, embodiment and performance, gender analysis, nonrepresentational theory, critical discourse analyses, [and] postcolonial theories" (Morgan et al. 2018, 185). This "critical turn" has itself been subject to "radical critique" (Bianchi 2009) for its overemphasis on questions of discourse, culture, and representation at the expenses of political economy and a historical materialist analysis of tourism's entanglements with capitalism and structural power. There is no doubt, however, that it constitutes a vital strand of tourism research in which the methodological and epistemological tools of anthropology have found much appreciation. Tucker's work, particularly her recent focus on issues of gender, postcolonialism, and affective dimensions of tourism (2009; Tucker and Akama 2009; Tucker and Boonabaana 2012), provides an excellent example of fruitful engagements by an anthropologist within the inter- and post-disciplinary field of tourism studies, and more particularly critical tourism studies.

In terms of the key disciplinary areas to which the study of tourism continues to make significant contributions, a first consideration is that ten years after Leite and Graburn's (2009) extensive review of the field, most of the themes they identified as part of classic, current, and future research directions continue to strongly move ahead. Readers are referred to their article for an assessment of the broad range of themes to which anthropological studies of tourism can contribute: among these are development, gender and sexuality, ethnicity, identity, and heritage ("classic concerns"); place, movement, cultural displays, the global ("current trajectories"); and medicine, power, media, activism, and kinship ("future directions"). Here, two major research directions, among others, are suggested that are fruitfully converging and overlapping with studies of tourism, to which anthropological approaches of tourism have much to offer. These are the areas of research on development and on heritage, which bring to the fore key related issues of power, poverty, inequality, property, memory, and culture.

Having moved beyond impact approaches, anthropological research on the entanglements between tourism and development remains a very important area of contribution well into the second decade of the 21st century, as illustrated, for instance by the monographs of Bianet Castellanos (2010), Chio (2014), Kockelman (2016), Feng (2017), Baptista (2017), and Taylor (2018), and by Borges de Lima and King's edited volume (2017). In some contexts, such as that of Spanish academia, the tourism-development nexus has become so seamless that Martínez Mauri (2015) speaks of a "touristification" of the anthropology of development in that country. Exploring the process by which tourism becomes development, and vice versa, Baptista's (2017) work raises important questions about the ethics and implications of such confluences and contributes to another growing body of scholarship on what may be seen as a growing "moralization" of tourism (cf. Butcher 2002). The volume edited by Mostafanezhad and Hannam (2014) and mono-

Page 18 of 52

PRINTED FROM the OXFORD RESEARCH ENCYCLOPEDIA, ANTHROPOLOGY (oxfordre.com/anthropology). (c) Oxford University Press USA, 2020. All Rights Reserved. Personal use only; commercial use is strictly prohibited (for details see Privacy Policy and Legal Notice). 


\section{Encountering Tourism}

graphs of Mathers (2010), Vastri (2013), and Mostafanezhad (2014) mark important steps in clarifying tourists' drive to "do good," and the way such desire is shaped by and captured in the current neoliberal context, including the broader (geo)political lessons and implications that can be read in such developments. Issues of ethics and morality are also at the center of Frenzel, Koens, and Steinbrink's (2013) edited collection on "slum tourism," and the monographs of Freire-Medeiros (2014), Larkins (2015), and Holst (2018), which provide new insights on the controversial tourism marketing and the visiting of impoverished neighborhoods in the Global South, shedding new light on broader reflections on power, poverty, and inequality in the contemporary world.

In parallel to this ongoing focus on tourism (as) development, a growing body of scholarship can be identified that is addressing processes of heritage-making. This strand of research has made significant contributions to current anthropological understandings of cultural property, material culture, the memorialization of the past, "living traditions," and their social, economic, and political entanglements into global "heritage regimes" (Bendix, Eggert, and Peselmann 2012; Geismar 2015). Building on the "invention of tradition" approach that took force in the 1980s, a fertile body of anthropological work explores the politics of heritage and the "global hierarchies of value" (Herzfeld 2004) that orient processes of heritagization. ${ }^{17}$ This field of scholarship is perhaps also one in which anthropologists have been more keen in "studying up" (Nader 1972), with researchers entering the corridors of institutional power to pay attention to the global institutions that govern heritage, set standards and canonize sites, and, increasingly sofollowing UNESCO's creation of the new "intangible heritage" category in 2003 (Kirshenblatt-Gimblett 2004)-also people and practices. The profusion of anthropological research on the often contentious processes of heritage-making, particularly in the past decade (2010s), attests to the vitality both of the very subjects under consideration-as processes of heritagization invest more and more domains of life-and of the research currently carried out. ${ }^{18}$ Accordingly, and not unlike tourism studies, heritage studies is also being established as a specialized research field with its own conferences, journals, and "critical heritage studies" association, created in 2012 to promote heritage as an area of critical inquiry. ${ }^{19}$

\section{Conclusion}

The advances in the areas of development and heritage (see "BUILDING DISCIPLINARY BRIDGES, DIFFUSING TOURISM") provide a good illustration of how tourism and its anthropological study are converging, if not merging, with related research areas, and seem to lend credit to the idea that we are increasingly confronted with a certain "touristification" of the world in which we live (Franklin 2008). Franklin's $(2003,2004,2008)$ approach to tourism as a form of ordering "encourages us to ask not what tourism means but what it does" $(2008,36)$. Accordingly, tourism "begins to seem less like 'behaviour' confined to distinctive 'tourist sites' and more like a network that enrolls people, objects and places into its extending lineages (heritages, resorts, ethnicities, natures, cityscapes, battlefields, landscapes, adrenaline thrills and so on)" $(2008,32) .{ }^{20}$ In this view, tourism 


\section{Encountering Tourism}

appears as a powerful driver of globalization, one that "(re)orders places, spaces, cities and cultures" $(2008,33)$, changing them in specific ways. Aestheticization, consumerism, place-making, touristification: these are among the key ordering effects of tourism that Franklin (2008) identifies. ${ }^{21}$ His insights on tourism highlight its growing embeddedness in many areas of life in the contemporary world and the increasing impossibility, as Picard showed in the case of Bali $(1992,1996)$, of teasing out its features as an external agent of change. ${ }^{22}$ Pointing in a similar direction, we may refer here to scholarship discerning a certain dilution in terms of the specificity of tourism practices and highlighting their increasingly blurred boundaries (see "MULTIPLYING 'THE TOURIST'”). Such a body of work argues for the interest of situating tourism among a broader range of "momentous mobilities" (Salazar 2018), voluntary forms of translocal mobility that are increasingly valued in the contemporary world. These include various kinds of discretionary educational, labor, and lifestyle mobilities, which, along with other privileged, emerging forms of neo or digital nomadism (D'Andrea 2007; Mancinelli 2018; Loloum 2018; Thompson 2019), can confound established boundaries between work, leisure, and travel, and complicate even further the task of singling out and delimiting tourist's motivations and typologies from other valued modalities of contemporary travel. ${ }^{23}$

If, on the one hand, theoretical recognition is found of a certain blurring of boundaries between various forms of valued mobility and that tourism has become "less a definable set of practices and more a way of living and organizing our sociotechnical relations" (Abram 2010, 232, drawing on Franklin), on the other hand, Abram (2010) also points out that "we cannot simply drop the recognition that at present a large part of the global economy and many national and local economies are categorized as tourism, and that this categorization includes businesses based on the exploitation of leisure, the encounter with difference (place, people, time), or at a basic level, staying in hotels" (2001, 233) - or, for that matter, AirBnb and other emerging forms of for-profit local accommodation, as may be added a decade after Abram's original remarks. In other words, as anthropologists, we are still required to follow actors as they identify, speak of, and work over something called "tourism"-what tourism means, what it generates, who profits or is excluded from it, and so on. Recent research on tourism, heritage-making, and its "excesses" in urban areas is useful in putting into perspective analytical approaches and emic understandings of the phenomenon. ${ }^{24}$ Characterizations of tourism, its omnipresence, and its "invasive" qualities are increasingly becoming the object of analysis, debate, and critique by scholars and activists resisting its encroachment on and transformation of the urban landscape, which affects life possibilities, notably as a result of "gentrification" (Smith 1987) and the expulsions linked to it. ${ }^{25}$ Here is a realm of research in which identifying the effects of tourism and explicit resistance to it (sometimes labeled "anti-tourism"), and teasing out its (dis)entanglements with (other) neoliberal processes of capital accumulation and dispossession, remains paramount. Compared to other responses to tourism in less privileged world contexts and rural areas, what perhaps distinguishes reactions in urban centers, notably in the global North, is that they tend to acquire more visibility and benefit from higher levels of mediatization, while pos- 


\section{Encountering Tourism}

sibly also being more capable of escaping the developmentalist dictates that tend to legitimize and push tourism economic agendas in more peripheral regions.

Reflecting on the state of anthropological interventions in the study of tourism, Leite and Graburn (2009) noted that, after a phase of maturity signaled by scholars setting out to specifically study tourism (Graburn and Jafari 1991), a further stage has been reached, marked by the integration of tourism as an element in anthropological research on a wide array of topics. In the ten years that have passed since their publication, scholars have continued to engage with questions and concerns that can be of broader interest to anthropology, in close dialog with the theories and conceptual developments taking place more generally within the discipline. What remains important is to continue building on earlier contributions so as not to reinvent what has been done already, and to move these contributions further along. The hope is that this article can help in the task. Looking at the state of current research and the paths traveled so far, what cannot be stressed enough is tourism's diversified role as an active agent of processes of globalization, and the potential of its anthropological study to shed further light on the way tourism is reshaping the way people understand and act upon a range of notions and areas that are at the core of anthropology's disciplinary concerns. Culture, ethnicity, identity, alterity, heritage, mobility, labor, commerce, hospitality, intimacy, development, and the environment - these are among the notions and entities worked over by tourism. Understanding how tourism operates and changes, what it means and does, leads to better understanding about how our world itself is changing. As anthropologists concerned with the contemporary, its ongoing transformations, and the power relations that inform the directionalities and qualities of such mutations, we must acknowledge the growing importance of tourism and pay attention to its heterogeneous expressions. Processes of touristification, themselves contextualized and ever evolving, are affecting an increasing range of areas of life on our planet, and anthropological interventions that carefully account for such processes are also a way to act on them and shape their future.

\section{AcknowledgmentsReading}

I am very grateful to Kathleen Adams, Nelson Graburn, Naomi Leite, as well as two anonymous reviewers, for their insightful comments and suggestions on earlier versions of the article. Any shortcomings are the author's sole responsibility.

\section{Further Reading}

Jamal, T., and M. Robinson, eds. 2009. The SAGE Handbook of Tourism Studies. London: SAGE.

MacCannell, D. (1977) 2013. The Tourist: A New Theory of the Leisure Class (With a New Introduction). Berkeley, CA: University of California Press.

Smith, V. L. ed. 1989. Hosts and Guests: The Anthropology of Tourism, 2nd ed. Philadelphia: University of Pennsylvania Press. 


\section{References}

Abram, S. 2010. "Anthropology, Tourism and Intervention?" In Thinking Through Tourism, edited by J. Scott and T. Selwyn, 231-253. London: Berg.

Abram, S., and J. Waldren. 1997. "Introduction: Tourists and Tourism - Identifying with People and Places." In Tourists and Tourism: Identifying with People and Places, edited by S. Abram, J. Waldren, and D. V. L. Macleod, 1-11. Oxford: Berg.

Abram, S., J. Waldren, and D V. L. Macleod, eds. 1997. Tourists and Tourism: Identifying with People and Places. Oxford: Berg.

Abu-Lughod, L. 1991. “Writing Against Culture.” In Recapturing Anthropology: Working in the Present, edited by R. G. Fox, 137-162. Santa Fe, NM: School of American Research.

Adams, K. M. 1984. "Come to Tana Toraja, 'Land of the Heavenly Kings': Travel Agents as Brokers in Ethnicity." Annals of Tourism Research 11 (3): 469-485.

Adams, K. M. 1993 “Club Dead, Not Club Med: Staging Death in Contemporary Tana Toraja (Indonesia)." Southeast Asian Journal of Social Science 21 (2): 59-69.

Adams K. M. 1995. "Making-up the Toraja? The Appropriation of Tourism, Anthropology, and Museums for Politics in Upland Sulawesi, Indonesia." Ethnology 34: 143-154.

Adams, K. M. 1998. "Domestic Tourism and Nation-Building in South Sulawesi." Indonesia and the Malay World 26 (75): 77-97.

Adams, K. M. 2004. "The Genesis of Touristic Imagery: Politics and Poetics in the Creation of a Remote Indonesian Island Destination." Tourist Studies 4 (2): 115-35.

Adams, K. M. 2005. “Generating Theory, Tourism, and 'World Heritage' in Indonesia: Ethical Quandaries for Anthropologists in an Era of Tourist Mania." NAPA Bulletin 23: 45-59.

Adams, K. M. 2006. Art as Politics: Re-crafting Identities, Tourism, and Power in Tana Toraja, Indonesia. Honolulu: University of Hawai'i Press.

Adams, V. 1992. "Tourism and Sherpas, Nepal: Reconstruction of Reciprocity." Annals of Tourism Research 19: 534-554.

Adler, J. 1989. “Origins of Sightseeing.” Annals of Tourism Research 16: 7-29.

Aime, M. 2005. L'incontro mancato. Turisti, nativi, immagini. Turin, Italy: Bollati Boringhieri.

Aime, M., ed. 2007. Antropologia del turismo. Special issue, La Ricerca Folklorica 56.

Amirou, R. 1995. Imaginaire touristique et sociabilités du voyage. Paris: Presses Universitaires de France.

Page 22 of 52

PRINTED FROM the OXFORD RESEARCH ENCYCLOPEDIA, ANTHROPOLOGY (oxfordre.com/anthropology). (c) Oxford University Press USA, 2020. All Rights Reserved. Personal use only; commercial use is strictly prohibited (for details see Privacy Policy and Legal Notice). 


\section{Encountering Tourism}

Amit, V., ed. 2007. Going First Class? New Approaches to Privileged Travel and Movement. Oxford: Berghahn Books.

Anderson, J., and H. Geismar, eds. 2017. The Routledge Companion to Cultural Property. London: Taylor \& Francis.

Andrews, H. 2011. The British on Holiday: Charter Tourism, Identity and Consumption. Bristol, UK: Channel View.

Andrews, H., and P. Gupta, eds. 2010. Researching Tourism: Reflexive Practice and Gender. Special issue, Journal of Tourism Consumption and Practice 2 (2).

Andrews, H., T. Jimura, and L. Dixon, eds. 2019. Tourism Ethnographies: Ethics, Methods, Application and Reflexivity. London: Routledge.

Aramberri, J. 2001. "The Host Should Get Lost: Paradigms in the Tourism Theory." Annals of Tourism Research 28 (3): 738-761.

Asensio, R. H., and B. Pérez Galán, eds. 2012. El turismo es cosa de pobres? Patrimonio cultural, pueblos indígenas y nuevas formas de turismo en América Latina. El Sauzal, Spain: Pasos Edita.

Ateljevic, I., A. Pritchard, and N. Morgan, eds. 2007. The Critical Turn in Tourism Studies. Oxford: Elsevier.

Babb, F. 2011. The Tourism Encounter: Fashioning Latin American Nations and Histories. Stanford, CA: Stanford University Press.

Badone, E., and S. Roseman, eds. 2004. Intersecting Journeys: The Anthropology of Pilgrimage and Tourism. Champaign, IL: University of Illinois Press.

Banaszkiewicz, M., and S. Owsianowska, eds. 2018. Anthropology of Tourism in Central and Eastern Europe: Bridging Worlds. London: Lexington Books.

Banducci, Á., Jr., and M. Barretto, eds. 2001. Turismo e identidade local: Uma visão antropológica. Campinas, Brazil: Papirus.

Baptista, J. A. 2017. The Good Holiday: Development, Tourism and the Politics of Benevolence in Mozambique. Oxford: Berghahn Books.

Barberani, S. 2006. Antropologia e turismo: Scambi e complicità culturali nell'area mediterranea. Milan: Edizioni Angelo Guerini.

Basu, P. 2007. Highland Homecomings: Genealogy and Heritage-Tourism in the Scottish Diaspora. London: Routledge.

Beeton, S. 2016. Film-Induced Tourism. Second Edition. Bristol, UK: Channel View Publications. 


\section{Encountering Tourism}

Bendix, R. 1989. “Tourism and Cultural Displays: Inventing Traditions for Whom?” Journal of American Folklore 102: 127-146.

Bendix, R., A. Eggert, and A. Peselmann, eds. 2012. Heritage Regimes and the State. Göttingen, Germany: Göttingen University Press.

Benson, A., ed. 2011. Volunteer Tourism: Theoretical Frameworks and Practical Applications. London: Routledge.

Benson, M., and K. O’Reilly, eds. 2009. Lifestyle Migration: Expectations, Aspirations and Experiences. Farnham, UK: Ashgate.

Bianchi, R. V. 2009. “The 'Critical Turn' in Tourism Studies: A Radical Critique.” Tourism Geographies 11 (4): 484-504.

Bianet Castellanos, M. 2010. A Return to Servitude: Maya Migration and the Tourist Trade in Cancún. Minneapolis: University of Minnesota Press.

Boissevain, J. 1977. “Tourism and Development in Malta.” Development and Change 8: 523-538.

Boissevain, J., ed. 1996. Coping with Tourists: European Reactions to Mass Tourism. Oxford: Berghahn Books.

Boorstin, D. J. 1964. The Image: A Guide to Pseudo-Events in America. New York: Atheneum.

Borges de Lima, I., and V. T. King, eds. 2017. Tourism and Ethnodevelopment: Inclusion, Empowerment and Self-Determination. London: Routledge.

Boullosa-Joly, M., M. Demanget, and D. Dumoulin Kervran, eds. 2010. Tourisme patrimonial et sociétés locales en Amérique latine. Special Issue, Cahiers des Amériques latines 65.

Bowman, G. 1996. "Passion, Power and Politics in a Palestinian Tourist Market." In The Tourist Image: Myths and Myth Making in Tourism, edited by T. Selwyn, 84-103. Chichester, UK: Wiley.

Breglia, L. C. 2006. Monumental Ambivalence: The Politics of Heritage. Austin: University of Texas Press.

Brennan, D. 2004. What's Love Got to Do with It? Transnational Desires and Sex Tourism in the Dominican Republic. Durham, NC: Duke University Press.

Brulotte, R. 2012. Between Art and Artifact: Archaeological Replicas and Cultural Production in Oaxaca, Mexico. Austin: University of Texas Press.

Brulotte, R., and M. Di Giovine, eds. 2014. Edible Identities: Food as Cultural Heritage. Burlington, UK: Ashgate. 


\section{Encountering Tourism}

Brumann, C., and D. Berliner, eds. 2016 World Heritage on the Ground: Ethnographic Perspectives. Oxford: Berghahn Books.

Bruner, E. M. 1994. "Abraham Lincoln as Authentic Reproduction." American Anthropologist 96 (2): 397-415. Revised and reprinted as chapter 5 in Bruner 2005.

Bruner, E. 1995. “The Ethnographer/Tourist in Indonesia”. In International Tourism: Identity and Change, edited by M.-F. Lanfant, J. B. Allcock, and E. M. Bruner, 224-241. London: SAGE.

Bruner, E. M. 1996. “Tourism in the Balinese Borderzone.” In Displacement, Diaspora, and Geographies of Identity, edited by S. Lavie and T. Swedenburg, 157-170. Durham, NC: Duke University Press. Revised and reprinted as chapter 7 in Bruner 2005.

Bruner, E. M. 1999. “Return to Sumatra: 1957, 1997." American Ethnologist 26 (2): 461477. Revised and reprinted as chapter 9 in Bruner 2005.

Bruner, E. M. 2001. "The Maasai and the Lion King: Authenticity, Nationalism, and Globalization in African Tourism." American Ethnologist 28 (4): 881-908. Revised and reprinted as chapter 2 in Bruner 2005.

Bruner, E. M. 2005. Culture on Tour: Ethnographies of Travel. Chicago: University of Chicago Press.

Bruner, E. M., and B. Kirshenblatt-Gimblett. 1994. "Maasai on the Lawn: Tourist Realism in East Africa." Cultural Anthropology 9 (4): 435-470. Revised and reprinted as chapter 1 in Bruner 2005.

Buchberger, S. 2014. “Can Social Unequals Be Friends? Western Tourists and Their Maghrebi Hosts Negotiate Moral Ambiguity.” Suomen Antropologi 39 (1): 37-52.

Bunten, A. C. 2008. "Sharing Culture or Selling Out? Developing the Commodified Persona in the Heritage Industry." American Ethnologist 35 (3): 380-395.

Bunten, A. C. 2015. So, How Long Have You Been Native?: Life as an Alaska Native Tour Guide. Lincoln: University of Nebraska Press.

Bunten, A. C., and N. Graburn, eds. 2018. Indigenous Tourism Movements. Toronto: University of Toronto Press.

Burns, G. L. 2004. "Anthropology and Tourism: Past Contributions and Future Theoretical Challenges." Anthropological Forum 14: 5-22.

Burns, P. M. 1999. An Introduction to Tourism and Anthropology. London: Routledge.

Butcher, T. 2002. The Moralisation of Tourism: Sun, Sand. . . and Saving the World? London: Routledge. 


\section{Encountering Tourism}

Cabezas, A. L. 2009. Economies of Desire: Sex and Tourism in Cuba and the Dominican Republic. Philadelphia: Temple University Press.

Callari, G. M., and B. Riccio, eds. 2001. Sguardi antropologici sul turismo. Special issue, Afriche e Orienti 3 (3-4).

Calvo, M. C., and M. J. Ramos. 2018. "Suddenly Last Summer: How the Tourist Tsunami Hit Lisbon." Revista Andaluza de Antropología 15: 47-73.

Cañada, E., and I. Murray, eds. 2019. Turistificación global. Perspectivas críticas en turismo. Barcelona: Icaria.

Canestrini, D. 2001. Trofei di viaggio: per una antropologia dei souvenir. Torino, Italy: Bollati Boringhieri.

Canestrini, D. 2004. Non sparate sul turista. Torino, Italy: Bollati Boringhieri.

Canosa, A., B. Moyle, C. Moyle, and B. Weiler. 2018. "Anthropology and Sociology in Tourism Doctoral Research." Tourist Studies 18 (4): 375-398.

Castañeda, Q. 1996. In the Museum of Maya Culture: Touring Chichén Itzá. Minneapolis: University of Minnesota Press.

Causey, A. 2003. Hard Bargaining in Sumatra: Western Travellers and Toba Bataks in the Marketplace of Souvenirs. Honolulu: University of Hawai'i Press.

Cauvin-Verner, C. 2007. Au désert. Une anthropologie du tourisme dans le Sud marocain. Paris: L’Harmattan.

Chabloz, N., and J. Raout, eds. 2009. Tourismes. La quête de soi par la pratique des autres. Special issue, Cahiers d'études africaines 49 (1-2): 193-194.

Chambers, E. 1997a. "Introduction: Tourism's Mediators." In Tourism and Culture: An Applied Perspective, edited by E. Chambers, 1-11. Albany: State University Press of New York.

Chambers, E., ed. 1997b. Tourism and Culture: An Applied Perspective. Albany: State University Press of New York.

Chambers, E. 2000. Native Tours: The Anthropology of Travel and Tourism. Long Grove, IL: Waveland Press.

Chambers, E. 2005. “Can the Anthropology of Tourism Make Us Better Travelers?” NAPA Bulletin 23: 27-44.

Chareyron, G., S. Cousin, J. Da-Rugna, and S. Jacquot. 2014. "Patrolling TripAdvisor: Re-Purposing Large Data-Sets in Tourism Research." EspacesTemps.net. 


\section{Encountering Tourism}

Cheer, J. M., C. Milano, and M. Novelli. 2019. "Tourism and Community Resilience in the Anthropocene: Accentuating Temporal Overtourism." Journal of Sustainable Tourism 27 (4): 554-572.

Cheong, S.-M., and M. L. Miller. 2000. "Power and Tourism: A Foucauldian Observation." Annals of Tourism Research 27 (2): 371-390.

Chio, J. 2014. A Landscape of Travel: The Work of Tourism in Rural Ethnic China. Seattle: University of Washington Press.

Cipollari, C., ed. 2009. Scenari Turistici. Rome: CISU.

Clifford, J. 1988. The Predicament of Culture: Twentieth-Century Ethnography, Literature, and Art. Cambridge, MA: Harvard University Press.

Cocola-Gant, A. 2018. “Tourism Gentrification." In Handbook of Gentrification Studies, edited by L. Lees and M. Phillips, 281-293. Cheltenham, UK: Edward Elgar.

Cohen, E. 1971. “Arab Boys and Tourist Girls in a Mixed Jewish-Arab Community.” International Journal of Comparative Sociology 12: 217-233.

Cohen, E. 1979. “A Phenomenology of Tourist Experiences.” Sociology 13: 179-201.

Cohen, E. 1988. "Authenticity and Commoditisation in Tourism." Annals of Tourism Research 15 (3): 371-386.

Cohen, E., and S. A. Cohen. 2015. "Beyond Eurocentrism in Tourism: A Paradigm Shift to Mobilities.” Tourism Recreation Research 40 (2): 157-168.

Cole, S., ed. 2018. Gender Equality and Tourism: Beyond Empowerment. Oxford: CABI.

Coles, T., and D. J. Timothy, eds. 2004. Tourism, Diasporas and Space. London: Routledge.

Colomb, C., and J. Novy, eds. 2017. Protest and Resistance in the Tourist City. London: Routledge.

Comaroff, J. L., and J. Comaroff. 2009. Ethnicity, Inc. Chicago: University of Chicago Press.

Cousin, S. 2008. "L’Unesco et la doctrine du tourisme culturel: Généalogie d'un 'bon' tourisme." Civilisations 57 (1-2): 41-56.

Cousin, S. 2011. Les miroirs du tourisme. Ethnographie de la Touraine du Sud. Paris: Descartes \& Cie.

Cousin, S., and J.-L. Martineau. 2009. "Le festival, le bois sacré et l’Unesco. Logiques politiques du tourisme culturel à Osogbo (Nigeria)." Cahiers d'Études africaines 49 (1-2): 337-364. 


\section{Encountering Tourism}

Cousin, S., and T. Apchain. 2016. “Tourisme et anthropologie: un tango de l'altérité," Mondes du Tourisme 12: 1-19.

Cresswell, T. 2006. On the Move: Mobility in the Modern Western World. London: Routledge.

Crick, M. 1985. "'Tracing' the Anthropological Self: Quizzical Reflections on Fieldwork, Tourism, and the Ludic." Social Analysis 17: 71-92.

Crick, M. 1995. "The Anthropologist as Tourist: An Identity in Question”. In International Tourism: Identity and Change, edited by M.-F. Lanfant, J.B. Allcock, and E.M. Bruner, 205223. London: SAGE.

Crick, M. 1989. "Representations of Tourism in the Social Sciences: Sun, Sex, Sights, Savings, and Servility." Annual Review of Anthropology 18: 307-344.

Dahles, H., and K. Bras, eds. 1999. "Entrepreneurs in Romance: Tourism in Indonesia.” Annals of Tourism Research 26 (2): 267-293.

Daigle, M. 2015. From Cuba with Love: Sex and Money in the Twenty-First Century. Oakland: University of California Press.

D’Andrea, A. 2007. Global Nomads: Techno and New Age as Transnational Countercultures in Ibiza and Goa. London: Routledge.

Dann, G. 2012. "Remodelling a Changing Language of Tourism: From Monologue to Dialogue and Trialogue." Pasos. Revista de Turismo y Patrimonio Cultural 10 (4): 59-70.

Demanget, M., D. Dumoulin Kervran, and M. Boullosa-Joly, eds. 2010. Tourisme patrimonial et sociétés locales en Amérique latine. Special issue, Cahiers des Amériques latines 65.

De Cesari, C. 2019. Heritage and the Cultural Struggle for Palestine. Stanford, CA: Stanford University Press.

De Cesari, C., and M. Herzfeld. 2015. “Urban Heritage and Social Movements.” In Global Heritage: A Reader, edited by L. Meskell, 171-195. Chichester, UK: Wiley Blackwell.

De Kadt, E. 1979. Tourism-Passport to Development? Perspectives on the Social and Cultural Effects of Tourism in Developing Countries. Oxford: Oxford University Press.

De Lugan, R., and P. Naef, eds. 2018. The Familiar and the Strange in Heritage and Tourism Encounters. Special issue, Journal of Anthropological Research 74 (4).

Del Marmol, C., M. Morell, and J. Chalcraft, eds. 2014. The Making of Heritage: Seduction and Disenchantment. London: Routledge.

Di Giovine, M. A. 2009. The Heritage-scape: UNESCO, World Heritage, and Tourism. Lanham, MD: Lexington Books. 


\section{Encountering Tourism}

Di Giovine, M. A., and D. Picard, eds. 2015. The Seductions of Pilgrimage: Sacred Journeys Afar and Astray in the Western Religious Tradition. London: Routledge.

Dodd, R., and R. W. Butler, 2019. Overtourism: Issues, Realities and Solutions. Berlin: De Gruyter.

Doquet, A., and O. Evrard, eds. 2008. Tourisme, mobilités et altérités contemporaines. Special issue, Civilisations 57 (1-2).

Douquet, A., and S. Le Menestrel, eds. 2006. Tourisme culturel, réseaux, et recompositions sociales. Special Issue, Autrepart 40.

Dumont, J.-P. 1977. “Review of The Tourist, by Dean MacCanell, 1976." Annals of Tourism Research 4 (4): 223-225.

Durkheim, E. 1912. Elementary Forms of Religious Life. London: Allen and Unwin.

Ebron, P. 2002. Performing Africa. Princeton, NJ: Princeton University Press.

Edensor, T. 1998. Tourists at the Taj: Performance and Meaning at a Symbolic Site. London: Routledge.

Elliott, A., R. Norum, and N. B. Salazar, eds. 2017. Methodologies of Mobility: Ethnography and Experiment. Oxford: Berghahn Books.

Errington, F., and D. Gewertz. 1989. "Tourism and Anthropology in a Post-Modern World." Oceania 60 (1): 37-54.

Favero, P. 2003. "Phantasms in a 'Starry' Place: Space and Identification in a Central New Delhi Market.” Cultural Anthropology 18 (4): 551-584.

Feifer, M. 1985. Going Places: The Ways of the Tourist from Imperial Rome to the Present Day. London: Macmillan.

Feldman, J. 2008. Above the Death Pits, Beneath the Flag: Youth Voyages to Poland and the Performance of Israeli National Identity. Oxford: Berghahn Books.

Feldman, J., and J. Skinner, eds. 2018. Tour Guides as Cultural Mediators. Special issue, Ethnologia Europaea 48 (2).

Feng, X. 2017. Tourism and Prosperity in Miao Land: Power and Inequality in Rural Ethnic China. London: Lexington Books.

Figueroa-Domecq, C., A. Pritchard, M. Segovia-Pérez, N. Morgan, and T. Villacé-Molinero. 2015. "Tourism Gender Research: A Critical Accounting." Annals of Tourism Research 52: 87-103.

Finney, B., and K. A. Watson, eds. 1975. A New Kind of Sugar: Tourism in the Pacific. Honolulu, Hawaii: East-West Center. 


\section{Encountering Tourism}

Forshee, J. 1999. "Domains of Pedaling: Souvenirs, Becak Drivers, and Tourism in Yogyakarta, Java." In Converging Interests: Traders, Travelers, and Tourists in Southeast Asia, edited by J. Forshee, C. Fink, and S. Cate, 293-317. Berkeley, CA: University of California Press.

Fox, R. G., and B. J. King, eds. 2002. Anthropology Beyond Culture. Oxford: Berg.

Franklin, A. 2003. Tourism: An Introduction. London: SAGE.

Franklin, A. 2004. "Tourism as an Ordering: Towards a New Ontology of Tourism," Tourist Studies 4 (3): 277-301.

Franklin, A. 2008. "The Tourism Ordering: Taking Tourism More Seriously as a Globalising Ordering." Civilisations 57 (1-2): 25-39.

Franquesa, J. 2013. “On Keeping and Selling: The Political Economy of Heritage Making in Contemporary Spain.” Current Anthropology 54 (3): 360-361.

Freire-Medeiros, B. 2014. Touring Poverty. London: Routledge.

Frenzel, F., K. Koens, and M. Steinbrink, eds. 2013. Slum Tourism: Poverty, Power and Ethics. London: Routledge.

Frey, N. 1998. Pilgrim Stories: On and Off the Road to Santiago. Berkeley, CA: University of California Press.

Frohlick, S. 2012. Sexuality, Women, and Tourism: Cross-Border Desires through Contemporary Travel. London: Routledge.

Frohlick, S., and J. Harrison, eds. 2008a. Engaging Ethnography in Tourist Research. Special issue, Tourist Studies 8 (5).

Frohlick, S., and J. Harrison. 2008b. “Engaging Ethnography in Tourist Research: An Introduction." Tourist Studies 8 (5): 5-18.

Fuller, N. 2009. Turismo y Cultura: Entre el entusiasmo y el recelo. Lima: Fondo Editorial de la Pontificia Universidad Católica del Perú.

Gardner, K., and D. Lewis. 1996. Anthropology, Development and the Post-Modern Challenge, London: Pluto Press.

Gascón, J., and E. Cañada, eds. 2016. Turismo residencial y gentrificación rural. El Sauzal, Spain: Pasos Edita.

GATE (Gemeinsamer Arbeitskraus Tourismus und Ethnologies). 2005. Ethnologie und Tourismus: Chancen, Perspektiven und Voraussetzungen für eine verstärkte Zusammenarbeit. Berlin: Gemeinsamer Arbeitskreis Tourismus und Ethnologie.

Geertz, C. 1963. Agricultural Involution. Berkeley, CA: University of California Press. 


\section{Encountering Tourism}

Geismar, H. 2013. Treasured Possessions: Indigenous Interventions into Cultural and Intellectual Property. Durham, NC: Duke University Press.

Geismar, H. 2015. "Anthropology and Heritage Regimes.” Annual Review of Anthropology 44: 71-85.

Glick Shiller, N., and N. Salazar, eds. 2013. Regimes of Mobility: Imaginaries and Relationalities of Power. Special issue, Journal of Ethnic and Migration Studies 39 (2).

Gmelch, S. 2004. Tourists and Tourism: A Reader. Long Grove, IL: Waveland Press.

Graburn, N. 1967. “The Eskimo and 'Airport Art'.” Trans-action 4 (10): 28-33.

Graburn, N. 1977. “Tourism: The Sacred Journey." In Hosts and Guests: The Anthropology of Tourism, edited by V. L. Smith, 17-31. Philadelphia: University of Pennsylvania Press.

Graburn, N., ed. 1983a. The Anthropology of Tourism. Special issue, Annals of Tourism Research 10 (1).

Graburn, N. 1983b. "The Anthropology of Tourism." Annals of Tourism Research 10 (1): 933.

Graburn, N. 2002. "The Ethnographic Tourist." In The Tourist as a Metaphor of the Social World, edited by G. M. S. Dann, 19-39. Oxford: CABI.

Graburn, N. 2017. “Key Figure of Mobility: The Tourist.” Social Anthropology 25 (1): 8396.

Graburn, N., M. Barretto, C. A. Steil, R. de A. Grünewald, and R. J. dos Santos, eds. 2009. Turismo e antropología: Novas abordagens. Campinas, Brazil: Papirus.

Graburn, N., and J. Jafari. 1991. "Introduction.” Tourism Social Science. Special issue, Annals of Tourism Research 18 (1): 1-25.

Grasseni, C. 2016. The Heritage Arena: Reinventing Cheese in the Italian Alps. Oxford: Berghahn Books.

Gravari-Barbas, M., and N. Graburn, eds. 2016. Tourism Imaginaries at the Disciplinary Crossroads: Place, Practice, Media. London: Routledge.

Greenwood, D. 1972. "Tourism as an Agent of Change: A Spanish-Basque Case." Ethnology 11 (1): 80-91.

Greenwood, D. 1977. "Culture by the Pound: An Anthropological Perspective on Tourism as Cultural Commoditization." In Hosts and Guests: The Anthropology of Tourism, edited by V. L. Smith, 129-137. Philadelphia: University of Pennsylvania Press.

Greenwood, D. 1982. “Cultural 'Authenticity'.” Cultural Survival Quarterly 6 (3): 27-28. 


\section{Encountering Tourism}

Greenwood, D. 1989. "Culture by the Pound: An Anthropological Perspective on Tourism as Cultural Commoditization." In Hosts and Guests: The Anthropology of Tourism, 2nd ed., edited by V. L. Smith, 171-185. Philadelphia: University of Pennsylvania Press.

Griffith, L. M., and J. Marion. 2017. Apprenticeship Pilgrimage: Developing Expertise through Travel and Training. Lanham, MD: Rowman \& Littlefield. 2017.

Gupta, A., and J. Ferguson. 1992. "Beyond 'Culture': Space, Identity, and the Politics of Difference.” Cultural Anthropology 7 (1): 6-23.

Habib, J. 2017. “On the Production of Knowledge and the Anthropology of Tourism.” American Anthropologist 119 (4): 741-744.

Han, M., and N. Graburn, eds. 2010. Tourism and Glocalization: Perspectives on East Asian Societies. Osaka: Senri Ethnological Studies.

Handler, R. 1988. Nationalism and the Politics of Culture in Quebec. Madison: The University of Wisconsin Press.

Handler, R., and J. Linnekin. 1984. “Tradition, Genuine or Spurious.” Journal of American Folklore 97 (2): 273-290.

Hannam, K., and I. Ateljevic, eds. 2007. Backpacker Tourism: Concepts and Profiles. Bristol, UK: Channel View Publications.

Hannam, K., and A. Diekmann, eds. 2010. Beyond Backpacker Tourism: Mobilities and Experiences. Bristol, UK: Channel View Publications.

Hannam, K., M. Sheller, and J. Urry. 2006. “Editorial: Mobilities, Immobilities and Moorings." Mobilities 1 (1): 1-22.

Harrison, J. 2003. Being a Tourist: Finding Meaning in Pleasure Travel. Vancouver: University of British Columbia Press.

Heinich, N. 2009. La Fabrique du patrimoine. De la cathédrale à la petite cuillère. Paris: Éditions de la Maison des sciences de l'homme.

Hernández-Ramírez, J. 2006. “Producción de singularidades y mercado global. El estudio antropológico del turismo.” Boletín Antropológico 66: 21-50.

Hernández-Ramírez, J. 2015. “El turismo como objeto de estudio. Análisis de la producción bibliográfica de los antropólogos españoles del turismo." Pasos: Revista de Turismo y Patrimonio Cultural 13 (2): 305-331.

Hernández-Ramírez, J., X. Pereiro Pérez, and R. Pinto, eds. 2015. Panorama de la Antropología del Turismo desde el Sur. Special issue, PASOS: Revista de Turismo y Patrimonio Cultural 13 (2). 


\section{Encountering Tourism}

Hertz, E., and S. Chappaz-Wirthner, eds. 2012. Ethnographies des pratiques patrimoniales: Temporalités, territoires, communautés. Special issue, Ethnographiques.org 24.

Hertz, E., F. Graezer Bideau, W. Leimgruber, and E. Munz, eds. 2018. Politiques de la tradition: Le patrimoine culturel immatériel. Lausanne, Switzerland: Presses polytechniques et universitaires romandes.

Herzfeld, M. 2004. The Body Impolitic: Artisans and Artifice in the Global Hierarchy of Value. Chicago: University of Chicago Press. .

Herzfeld, M. 2009. Evicted from Eternity: The Restructuring of Modern Rome. Chicago: University of Chicago Press.

Hiernaux, D., and C. I. González. 2014. “Turismo y gentrificación: pistas teóricas sobre una articulación." Revista de geografía Norte Grande 58: 55-70.

Hitchcock, M. 1998. "Tourism, Taman Mini and National Identity." Indonesia and the Malay World 26 (74): 124-35.

Hobsbawn, E., and T. Ranger, eds. 1983. The Invention of Tradition. Cambridge, UK: Cambridge University Press.

Hodgson, D. L. 2002. "Introduction: Comparative Perspectives on the Indigenous Rights Movement in Africa and the Americas." American Anthropologist 104 (4): 1037-1049.

Hollinshead, K., I. Ateljevic, and N. Ali, eds. 2009 Worldmakings of Tourism. Special issue, Tourism Geographies 11 (4).

Hollinshead, K., and R. Suleman. 2018. "The Everyday Instillations of Worldmaking: New Vistas of Understanding on the Declarative Reach of Tourism." Tourism Analysis 23 (2): 201-213.

Holst, T. 2018. The Affective Negotiation of Slum Tourism: City Walks in Delhi. London: Routledge.

Hom Cary, S. 2004. “The Tourist Moment.” Annals of Tourism Research 31 (1): 61-77.

Inhorn, M. 2015. Cosmopolitan Conceptions: IVF Sojourns in Global Dubai. Durham, NC: Duke University Press.

Insart, C., and A. Leblon, eds. 2012. Au-delà du consensus patrimonial: Résistances et usages contestataires du patrimoine. Special issue, Civilisations 61 (1).

Isnart, C., and C. Sonia, eds. 2014. Circulating Heritage: Mediation and Recycling of the Cultural Heritage Items, Devices and Values. Special issue, Cultura. International Journal of Philosophy of Culture and Axiology 11 (2).

Jacobs, J. 2010. Sex, Tourism and the Postcolonial Encounter: Landscapes of Longing in Egypt. Farnham, UK: Ashgate. 


\section{Encountering Tourism}

Jacobsen, C. 2018. Tourism and Indigenous Heritage in Latin America: As Observed through Mexico's Magical Village Cuetzalan. London: Routledge.

Jóhannesson, G. T. 2005. “Tourism Translations. Actor-Network Theory and Tourism Research." Tourist Studies 5 (2): 133-150.

Jóhannesson, G. T., C. Ren, and R. van der Duim, eds. 2015. Tourism Encounters: Ontological Politics of Tourism Development. Farnham, UK: Ashgate.

Kahn, M. 2000. "Tahiti Intertwined: Ancestral Land, Tourist Postcard, and Nuclear Test Site." American Anthropologist 102 (1): 7-26.

Kaplan, L., and M. Shiff. 2016. "Mapping Ararat: An Augmented Reality Walking Tour for an Imaginary Jewish Homeland.” Anthrovision 4 (2): 1-23.

Kaspin, D. 1997. “On Ethnographic Authority and the Tourist Trade: Anthropology in the House of Mirrors." Anthropological Quarterly 70 (2): 53-57.

Kaul, A. 2009. Turning the Tune: Traditional Music, Tourism, and Social Change in an Irish Village. Oxford: Berghahn.

Keesing, R. 1989. "Creating the Past: Custom and Identity in the Contemporary Pacific." The Contemporary Pacific 1 (1-2): 19-42.

Keyes, C., and P. van den Berghe, eds. 1984. Tourism and Ethnicity. Special issue, Annals of Tourism Research 11 (3).

Kinnaird, V., and D. Hall, eds. 1994. Tourism: A Gender Analysis. Chichester, UK: Wiley.

Kirshenblatt-Gimblett, B. 1998. Destination Culture: Tourism, Museums, and Heritage. Berkeley, CA: University of California Press.

Kirshenblatt-Gimblett, B. 2004. "Intangible Heritage as Metacultural Production.” Museum International 56 (1-2): 52-64.

Kockelman, P. 2016. The Chicken and the Quetzal: Incommensurate Ontologies and Portable Values in Guatemala's Cloud Forest. Durham, NC: Duke University Press.

Koens, K., A. Postma, and B. Papp. 2018 “Is Overtourism Overused? Understanding the Impact of Tourism in a City Context." Sustainability 10 (12): 1-15.

Korstanje, M. E., ed. 2015. Antropologia del turismo. Special issue, Revista de Antropología Experimental 15.

Kummels, I. 2005. "Love in the Time of Diaspora: Global Markets and Local Meaning in Prostitution, Marriage and Womanhood in Cuba." Iberoamericana 5 (20): 7-26.

Lagunas, D. ed. 2007. Antropología y turismo. Claves culturales y disciplinarias. Mexico City: Plaza y Valdés. 


\section{Encountering Tourism}

Lanfant, M.-F. 1980. "Introduction: Tourism in the Process of Internationalization.” International Social Science Journal 32 (1): 14-43.

Lanfant, M.-F., J. B. Allcock, and E. M. Bruner, eds. 1995. International Tourism: Identity and Change. London: SAGE.

Larkins, E. M. R. 2015. The Spectacular Favela: Violence in Modern Brazil. Oakland: University of California Press.

Larsen, P. B. ed. 2018. World Heritage and Human Rights: Lessons from the Asia-Pacific and Global Arena. London: Routledge.

Leach, E. R. 1961. “Time and False Noses.” In Rethinking Anthropology, edited by E. R. Leach, 132-136. London: Athlone.

Lean, G., R. Staiff, and E. Waterton, eds. 2017. Travel and Representation. Oxford: Berghahn Books.

Leite, N. 2005. "Travels to an Ancestral Past: On Diasporic Tourism, Embodied Memory, and Identity." Antropologicas 9: 273-302.

Leite, N. 2017. Unorthodox Kin: Portuguese Marranos and the Global Search for Belonging. Oakland: University of California Press.

Leite, N., Q. E. Castañeda, and K. M. Adams, eds. 2019. The Ethnography of Tourism: Edward Bruner and Beyond. Lanham, MD: Rowman \& Littlefield.

Leite, N., and N. Graburn. 2009. "Anthropological Interventions in Tourism Studies." In The SAGE Handbook of Tourism Studies, edited by T. Jamal and M. Robinson, 33-64. London: SAGE.

Lévy-Strauss, C. 1955. Tristes Tropiques. Paris: Plon.

Le Menestrel, S. 1999. La voie des Cadiens. Tourisme et identité en Louisiane. Paris: Belin.

Liestøl, G., C. S. Ritter, and I. Ibrus. 2019. "Audiovisual Industries and Tourism: Forms of Convergence." In Emergence of Cross-Innovation Systems: Audiovisual Industries Co-innovating with Education, Health Care and Tourism, edited by I. Ibrus, 165-172. Bingley, UK: Emerald.

Linnekin, J. S. 1983. "Defining Tradition: Variations on the Hawaiian Identity.” American Ethnologist 10 (2): 241-252.

Little, K. 2020. On the Nervous Edge of an Impossible Paradise: Affect, Tourism, Belize. Oxford: Berghahn.

Little, W. E. 2004. Mayas in the Marketplace: Tourism, Globalization, and Cultural Identity. Austin: University of Texas Press. 


\section{Encountering Tourism}

Löfgren, O. 1999. On Holiday. A History of Vacationing. Berkeley, CA: University of California Press.

Lofgren, O. 2001. "Know Your Country: A Comparative Perspective on Tourism and Nation Building in Sweden." In Being Elsewhere: Tourism, Consumer Culture and Identity in Modern Europe and North America, edited by S. Baranowski and E. Furlough, 137-154. Ann Arbor: University of Michigan Press.

Loloum, T. 2018. "Faire de loisirs travail: les conditions sociales des reconversions professionnelles dans le tourisme." Loisir et Société 41 (2): 311-330.

Long, N., and A. Long. 1992. Battlefields of Knowledge: The Interlocking of Theory and Practice in Social Research and Development. London: Routledge.

López-Santillán, A. 2017. “Development, Power, and Exclusionary Politics: Tracing Articulations of Scale in Tourism Production in Mexico." American Anthropologist 119 (4): 725730.

Lowenthal, D. 1996. Possessed by the Past: The Heritage Crusade and the Spoils of History. Cambridge, UK: Cambridge University Press.

MacCannell, D. 1973. "Staged Authenticity: On Arrangements of Social Space in Tourist Settings.” The American Journal of Sociology 79 (3): 589-603.

MacCannell, D. 1976. The Tourist: A New Theory of the Leisure Class. London: Macmillan.

MacCarthy, M. 2016. Making the Modern Primitive: Cultural Tourism in the Trobriand Islands. Honolulu: University of Hawai'i Press.

MacDonald, S. 2013. Memorylands: Heritage and Identity in Europe Today. London: Routledge.

Mancinelli, F. 2008. "La etnógrafa-guía. Técnicas y metodología de investigación.” (Con)textos. Revista d'antropologia i investigació social 20082: 103-110.

Mancinelli, F. 2017. Zafimaniry: l'invention d'une tribu. Art ethnique, patrimoine immatériel et tourisme. Paris: L’Harmattan.

Mancinelli, F. 2018. "A Practice of Togetherness: Home Imaginings in the Life of LocationIndependent Families." International Journal of Tourism Anthropology 6 (4): 307-322.

Manjavacas, J. M. ed. 2018 Actividades turísticas, ciudad y patrimonio cultural: Miradas críticas. Special issue, Revista Andaluza de Antropología 15.

Maoz, D. 2006. “The Mutual Gaze.” Annals of Tourism Research 33 (1): 221-239.

Marschall, S. ed. 2017. Tourism and Memories of Home: Migrants, Displaced People, Exiles, and Diasporic Communities. Bristol, UK: Channel View. 
Martínez Mauri, M. 2015. "Una mirada sobre la turistificación de la antropología del desarrollo en el estado Español.” PASOS. Revista de turismo y patrimonio cultural 13 (2): 347-358.

Mathers, K. 2010. Travel, Humanitarianism, and Becoming American in Africa. New York: Palgrave Macmillan.

McCabe, S. 2005. “'Who Is a Tourist?’ A Critical Review.” Tourist Studies 5 (1): 85-106.

McKean P.-F. 1977. "Toward a Theoretical Analysis of Tourism: Economic Dualism and Cultural Involution in Bali." In Hosts and Guests: The Anthropology of Tourism, edited by V. L. Smith, 93-107. Philadelphia: University of Pennsylvania Press.

Meisch, L. 2002. Andean Entrepreneurs: Otavalo Merchants and Musicians in the Global Arena. Austin: University of Texas Press.

Meiu, G. P. 2017. Ethno-Erotic Economies: Sexuality, Money, and Belonging in Kenya. Chicago: Chicago University Press.

Meskell, L. 2012. The Nature of Heritage: The New South Africa. Oxford: Blackwell.

Meskell, L. ed. 2015. Global Heritage: A Reader. Chichester, UK: Wiley.

Meyer, B., and M. van de Port, eds. 2018. Sense and Essence: Heritage and the Cultural Production of the Real. Oxford: Berghahn Books.

Michaud, J. 2001. "Anthropologie, tourisme et sociétés locales au fil des textes." Anthropologie et Sociétés 25 (2): 15-33.

Michel, F. ed. 1998a. Tourismes, touristes, sociétés. Paris: L’Harmattan.

Michel, F. 1998b. “Des manières d'être et de faire du touriste et de l'anthropologue.” In Tourismes, Touristes, Sociétés, edited by F. Michel, 35-44. Paris: L'Harmattan.

Michel, F. 2000. Désirs d'ailleurs: Essai d'anthropologie des voyages. Paris: Armand Colin.

Milano, C. 2017. "Otherness Anthropologies: Toward Ibero-American Anthropologies of Tourism.” American Anthropologist 119 (4): 736-741.

Milano, C., M. Novelli, and J. M. Cheer, eds. 2019. Overtourism and Tourismphobia: A Journey Through Four Decades of Tourism Development, Planning and Local Concerns. Special issue, Tourism Planning and Development 16 (4).

Montero, C. G. 2018. "A Critical Look at the State of Tourism Studies in Anthropology in Latin America and the Caribbean." Tourism Analysis 23 (2): 249-259.

Montero, C. G. 2019. “Tourism”. Oxford Bibliographies. 
Morell, M. 2009. "Fent barri: Heritage Tourism Policy and Neighbourhood Scaling in Ciutat de Mallorca." Etnografica 13 (2): 343-372.

Morgan, N., A. Pritchard, S. Causevic, and L. Minnaert. 2018. "Ten Years of Critical Tourism Studies: Reflections on the Road Less Traveled.” Tourism Analysis 23 (2): 183187

Mostafanezhad, M. 2014. Volunteer Tourism: Popular Humanitarianism in Neoliberal Times. London: Ashgate.

Mostafanezhad, M., and K. Hannam, eds. 2014. Moral Encounters in Tourism. Farnham, UK: Ashgate.

Munz, H. 2016. La transmission en jeu. Apprendre, pratiquer, patrimonialiser l'horlogerie en Suisse. Neuchâtel, Switzerland: Éditions Alphil and Presses universitaires suisses.

Murray, A. E. 2017. Footprints in Paradise: Ecotourism, Local Knowledge, and Nature Therapies in Okinawa. Oxford: Berghahn Books.

Nader, L. 1972. “Up the Anthropologist-Perspectives Gained from Studying Up.” In Reinventing Anthropology, edited by D. Hymes, 284-311. New York: Pantheon.

Naef, P. 2016. La ville-martyre. Geneva, Switzerland: Slatkine.

Nahman, M. R. 2016. "Reproductive Tourism: Through the Anthropological 'Reproscope'." Annual Review of Anthropology 45: 417-432.

Naraindas, H., and C. Bastos. 2015. Healing Holidays: Itinerant Patients, Therapeutic Locales and the Quest for Health. London: Routledge.

Nash, D. 1977. “Tourism as a Form of Imperialism.” In Hosts and Guests: The Anthropology of Tourism, edited by V. L. Smith, 33-47. Philadelphia: University of Pennsylvania Press.

Nash, D. 1981. “Tourism as an Anthropological Subject.” Current Anthropology 22 (5): 461-481.

Nash, D. 1996. Anthropology of Tourism. Oxford: Pergamon.

Nash, D. 2007. The Study of Tourism: Anthropological and Sociological Beginnings. Amsterdam: Elsevier.

Nash, D., and V. Smith. 1991. "Anthropology and Tourism." Annals of Tourism Research 18 (1): 12-25.

Neveling, P., and C. Wergin. 2009. "Projects of Scale-Making: New Perspectives for the Anthropology of Tourism." Etnografica 13 (2): 315-342. 
Ness, S. A. 2016. Choreographies of Landscape: Signs of Performance in Yosemite National Park. Oxford: Berghahn Books.

Nogués-Pedregal, A.-M. 2009. “Genealogía de la difícil relación entre antropología social y turismo." PASOS: Revista de turismo y patrimonio cultural 7 (1): 43-56.

Nogués-Pedregal, A.-M., ed. 2012. Culture and Society in Tourism Contexts. Bingley, UK: Emerald.

Nogués-Pedregal, A.-M. 2019. “Anthropological Contributions to Tourism Studies.” Annals of Tourism Research 75: 227-237.

Norum, R. E. 2013. “The Unbearable Likeness of Being a Tourist: Expats, Travel and Imaginaries in the Neo-Colonial Orient." International Review of Social Research 3 (1): 27-47.

Nuñez, T. A. 1977. "Touristic Studies in Anthropological Perspective." In Hosts and Guests: The Anthropology of Tourism, edited by V. L. Smith, 207-216. Philadelphia: University of Pennsylvania Press.

Nuñez, T. A. 1963. "Tourism, Tradition, and Acculturation: Weekendismo in a Mexican Village." Ethnology 2 (3): 347-352.

Nyíri, P. 2006. Scenic Spots: Chinese Tourism, the State, and Cultural Authority. Seattle: University of Washington Press.

Oemichen Bazán, C., ed. 2013. Enfoques antropológicos sobre el turismo contemporáneo. Mexico City: UNAM-IIA.

Oskam, J. A. 2019. The Future of Airbnb and the "Sharing Economy": The Collaborative Consumption of Our Cities. Bristol, UK: Channel View.

Owsianowska, S., and R. Winiarski, eds. 2017. Antropologia Turystyki. Krakow, Poland: University of Physical Education in Krakow Press.

Palmer, C., and H. Andrews, eds. 2019. Tourism and Embodiment. London: Routledge.

Palou Rubio, S. 2014. "The Anthropological Study of Tourism in Spain: Notes about a Brief Anthropological Culture Dedicated to the Study of Tourism." Anthropology News 55 (9-10): 31.

Palou Rubio, S., and F. Mancinelli, eds. 2018a. Diàlegs d'antropologia i turisme. Etnografies i debats contemporanis. Special issue, Quaderns de l'Institut Català d'Antropologia 32: 5-28.

Palou Rubio, S., and F. Mancinelli. 2018b. "El turismo como refractor.” Quaderns de l'Institut Català d'Antropologia 32. 


\section{Encountering Tourism}

Pemberton, J. 1994. "Recollections from 'Beautiful Indonesia' (Somewhere Beyond the Post-Modern).” Public Culture 6 (2): 241-262.

Peng, Z. 2004. Anthropology of Tourism. Beijing: Ethnic Publishing House [in Chinese].

Pereiro, X. 2009. Turismo cultural: Uma visão antropológica. El Sauzal, Spain: Pasos Edita.

Pereiro, X., and F. Fernandes. 2015. "Antropologia e turismo: Dos trilhos, atores e espaços à genealogia da turistificacão da antropologia em Portugal." PASOS: Revista de turismo y património cultural 13 (2): 333-346.

Pereiro, X., and F. Fernandes. 2018. Antropologia e turismo: Teorias, métodos e praxis. El Sauzal, Spain: Pasos Edita.

Picard, D. 2011. Tourism, Magic and Modernity: Cultivating the Human Garden. Oxford: Berghahn Books.

Picard, D., and S. Buchberger, eds. 2013. Couchsurfing Cosmopolitanisms: Can Tourism Make a Better World? Bielefeld, Germany: Transcript Verlag.

Picard, D., and M. A. Di Giovine, eds. 2014. Tourism and the Power of Otherness: Seductions of Difference. Bristol, UK: Channel View.

Picard, D., and M. Robinson, eds. 2012. Emotion in Motion: Tourism, Affect and Transformation. Farnham, UK: Ashgate.

Picard, M. 1979. Sociétés et Tourisme. Réflexions pour la Recherche et l'action. Paris: UNESCO.

Picard, M. 1992. Tourisme culturel et culture touristique à Bali. Paris: L’Harmattan.

Picard, M. 1996. Bali: Cultural Tourism and Tourist Culture. Singapore: Archipelago.

Picard, M. 1997. "Cultural Tourism, Nation-Building, and Regional Culture: The Making of a Balinese Identity." In Tourism, Ethnicity, and the State in Asian and Pacific Societies, edited by M. Picard and D. Wood, 191-214. Honolulu: University of Hawai'i Press.

Picard, M. 2007. "From Turkey to Bali: Cultural Identity as Tourist Attraction.” In The Study of Tourism: Anthropological and Sociological Beginnings, edited by D. Nash, 167183. Amsterdam: Elsevier.

Picard, M., and R. E. Wood, eds. 1997. Tourism, Ethnicity, and the State in Asian and Pacific Societies. Honolulu: University of Hawai'i Press.

Pieroni, R., and P. Naef. 2019. "Exploring New Frontiers? 'Neo-Slumming' and Gentrification as a Tourism Resource." International Journal of Tourism Cities 5 (3): 338353. 
Pinto, R. 2015. “O turismo na tradicão antropológica brasileira.” PASOS: Revista de turismo y património cultural 13 (2): 295-304.

Pinto, R., and X. Pereiro. 2010. "Turismo e antropologia: Contribuições para um debate plural." Revista turismo \& desenvolvimento 1 (13): 447-454.

Piscitelli, A. 2013. Trânsitos: Brasileiras nos mercados transnacionais do sexo. Rio de Janeiro, Brazil: Editora da Universidade do Estado do Rio de Janeiro.

Pi-Sunyer, O. 1977. "Through Native Eyes: Tourists and Tourism in a Catalan Maritime Community." In Hosts and Guests: The Anthropology of Tourism, edited by V. L. Smith, 149-155. Philadelphia: University of Pennsylvania Press.

Ploner, J., and P. Naef, eds. 2017. Tourism, Conflict and Contested Heritage in Former Yugoslavia. London: Routledge.

Pritchard, A., N. Morgan, I. Ateljevic, and C. Harris, eds. 2007. Tourism and Gender: Embodiment, Sensuality, and Experience. Oxford: CABI.

Rancew-Sikora, D., ed. 2009. Podróż i miejsce w perspektywie antropologicznej. Gdansk, Poland: Wydawnictwo Uniwersytetu Gdanskiego.

Rauch, A., ed. 2002. Touristes, autochtones: qui est l'étranger? Special issue, Ethnologie française 32 (3).

Redfield, R. 1941. The Folk Culture of Yucatan. Chicago: University of Chicago Press.

Redfield, R., R. Linton, and M. J. Herskovits. 1936. "A Memorandum for the Study of Acculturation." American Anthropologist 38 (1): 149-152.

Regi, T. 2014. "The Anthropology of Tourism and Development in Africa: Mobile Identities in a Pastoral Society in South-Ethiopia." International Journal of Tourism Anthropology 3 (4): 302-324.

Restrepo, E., and A. Escobar. 2005. “'Other Anthropologies and Anthropology Otherwise': Steps to a World Anthropologies Framework." Critique of Anthropology 25 (2): 99-129.

Ribeiro, G. L., and A. Escobar, eds. 2006. World Anthropologies: Disciplinary Transformations within Systems of Power. Oxford: Berg.

Richards, G., and J. Wilson, eds. 2004. The Global Nomad: Backpacker Travel in Theory and Practice. Bristol: Channel View Publications.

Ritter, C. S. 2017. “Travel Technology.” In The SAGE International Encyclopedia of Travel and Tourism, edited by L. L. Lowry, 1332-1336. Thousand Oaks, CA: SAGE.

Roberts, L., and H. Andrews. 2013. "(Un)doing Tourism Anthropology: Outline of a Field of Practice." Journal of Tourism Challenges and Trends 6 (2): 13-38. 
Rodenberg, J., and P. Wagenaar, eds. 2018. Cultural Contestation: Heritage, Identity and the Role of Government. New York: Palgrave Macmillan.

Roux, S. 2011. No Money, No Honey. Economies intimes du tourisme sexuel en Thailande. Paris: La Découverte.

Saidi, H., ed. 2010. Tourisme culturel. Special issue, Ethnologies 32 (2).

Salazar, N. B. 2005. "Tourism and Glocalization: 'Local' Tour Guiding." Annals of Tourism Research 32 (3): 628-646.

Salazar, N. B. 2010. Envisioning Eden: Mobilizing Imaginaries in Tourism and Beyond. Oxford: Berghahn Books.

Salazar, N. B. 2012. “Tourism Imaginaries: A Conceptual Approach.” Annals of Tourism Research 39 (2): 863-882.

Salazar, N. B. 2013. "Imagineering Otherness: Anthropological Legacies in Contemporary Tourism.” Anthropological Quarterly 86 (3): 669-696.

Salazar, N. B. 2017. “Anthropologies of Tourism: What's in a Name?” American Anthropologist 119 (4): 723-725.

Salazar, N. B. 2018. Momentous Mobilities: Anthropological Musings on the Meaning of Travel. Oxford: Berghahn Books.

Salazar, N. B., and J. Coates, eds. 2017. Key Figures of Mobility. Special issue, Social Anthropology 25 (1).

Salazar, N. B., and N. Graburn, eds. 2014. Tourism Imaginaries: Anthropological Approaches. Oxford: Berghahn Books.

Salazar, N. B., and K. Jayaram, eds. 2016. Keywords of Mobility: Critical Engagements. Oxford: Berghahn Books.

Salazar, N. B., and A. Smart, eds. 2011. Anthropological Takes on (Im)mobility. Special issue, Identities: Global Studies in Culture and Power 18 (6).

Sampaio, S. 2013. "Estudar o turismo hoje: para uma revisão critica dos estudos de turismo." Etnográfica 17 (1): 167-182.

Sampaio, S., V. Simoni, and C. Isnart, eds. 2014. Tourism and Transformation: Negotiating Metaphors, Experiencing Change. Special issue, Journal of Tourism and Cultural Change $12(2)$.

Santana Talavera, A. 1997. Antropología y turismo: ¿Nuevas hordas, viejas culturas? Barcelona: Ariel. 


\section{Encountering Tourism}

Santos, B. de S. 2006. Conocer desde el Sur: Para una cultura política emancipatoria. Lima, Peru: Fondo Editorial de la Facultad de Ciencias Sociales UNMSM.

Scott, J., and T. Selwyn, eds. 2010. Thinking through Tourism. Oxford: Berg.

Selwyn, T. 1993. "Peter Pan in South-East Asia: Views from the Brochures." In Tourism in South East Asia, edited by M. Hitchcock, V. T. King, and M. Parnwell, 117-137. London: Routledge.

Selwyn, T. 1994. "The Anthropology of Tourism: Reflections on the State of the Art." In Tourism: The State of the Art, edited by A. V. Seaton, 729-736. Chichester, UK: Wiley.

Selwyn, T. ed. 1996. The Tourist Image: Myths and Myth Making in Tourism. Chichester, UK: Wiley.

Selwyn, T. 2007. "The Political Economy of Enchantment: Formations in the Anthropology of Tourism." Suomen Antropologi 32 (2): 48-70.

Sequera, J., and J. Nofre. 2018. "Shaken, Not Stirred: New Debates on Touristification and the Limits of Gentrification." City 22 (5-6): 843-855.

Serrano-Barquín, R. C., G. Rondríguez Muñoz, and Y. D. Palmas Castrejón, eds. 2018. Turismo y Género una Mirada desde Iberoamérica. Toluca de Lerdo: Universidad Autónoma del Estado de México.

Shao, J., M. Scarpino, Y. Lee, and U. Gretzel. 2012. "Media-Induced Voluntourism in Yunnan, China." Tourism Review International 15 (3): 277-292.

Sharpley, Richard, and Philip R. Stone, eds. 2009. The Darker Side of Travel: The Theory and Practice of Dark Tourism. Bristol, UK: Channel View.

Sheller, M., and J. Urry. 2006. “The New Mobilities Paradigm.” Environment and Planning A 38 (2): 207-226.

Silva, L. 2014. Património, Ruralidade e Turismo: Etnografias de Portugal Continental e dos Açores. Lisbon: Imprensa de Ciências Sociais.

Silva, L., and P. M. Santos. 2012. Ethnographies of Heritage and Power. Special issue, International Journal of Heritage Studies 18 (5).

Silva, M. C., ed. 2013 Castelos a Bombordo: Etnografias de patrimónios africanos e memórias portuguesas. Lisbon, Portugal: Etnográfica Press.

Simoni, V. 2008. "Shifting Power: The (De)Stabilization of Asymmetries in the Realm of Tourism in Cuba." Tsansta 13: 89-97.

Simoni, V. 2009. "Scaling Cigars in Cuba's Tourism Economy.” Etnografica 13 (2): 417438. 
Simoni, V. 2012. "Dancing Tourists: Tourism, Party and Seduction in Cuba." In Emotion in Motion: Tourism, Affect and Transformation, edited by D. Picard and M. Robinson, 267281. Farnham, UK: Ashgate.

Simoni, V. 2013. "Intimate Stereotypes: Becoming Caliente in Touristic Cuba." Civilisations 62 (1-2): 181-197.

Simoni, V. 2014a "Coping with Ambiguous Relationships: Sex, Tourism, and Transformation in Cuba." Journal of Tourism and Cultural Change 12 (2): 166-183.

Simoni, V. 2014b. "From Tourist to Person: The Value of Intimacy in Touristic Cuba." Journal of Tourism and Cultural Change 12 (3): 280-292.

Simoni, V. 2014c. "The Morality of Friendship in Touristic Cuba." Suomen Antropologi 39 (1): 19-36.

Simoni, V. 2016a. Tourism and Informal Encounters in Cuba. Oxford: Berghahn Books.

Simoni, V. 2016b. "Ethnography, Mutuality, and the Utopia of Love and Friendship in Touristic Cuba." Journal of the Anthropological Society of Oxford 8 (1): 143-167.

Simoni, V. 2018. "Approaching Difference, Inequality, and Intimacy in Tourism: A View from Cuba." Journal of Anthropological Research 74 (4): 503-525.

Simoni, V. 2019. "Living In and Reaching Beyond the Touristic Borderzone: A View from Cuba." In The Ethnography of Tourism: Edward Bruner and Beyond, edited by N. Leite, Q. E. Castañeda, and K. M. Adams, 107-123. Lanham, MD: Rowman \& Littlefield.

Simoni, V., and S. McCabe. 2008. "From Ethnographers to Tourists and Back Again: On Positioning Issues in the Anthropology of Tourism." Civilisations 57 (1-2): 173-189.

Simonicca, A. 1997. Antropologia del turismo: Strategie di ricerca e contesti etnografici. Rome: Carocci.

Simonicca, A. 2004. Turismo e società complesse: Saggi Antropologici. Rome: Meltemi.

Skinner, J. ed. 2012. Writing the Dark Side of Travel. Oxford: Berghahn Books.

Skinner, J., and A. Theodossopoulos, eds. 2011. Great Expectations: Imagination and Anticipation in Tourism. Oxford: Berghahn Books.

Smith, L. 2006. Uses of Heritage. London: Routledge.

Smith, N. 1987. "Gentrification and the Rent Gap." Annals of the Association of American Geographers 77 (3): 462-465.

Smith, V. L., ed. 1977a. Hosts and Guests: The Anthropology of Tourism. Philadelphia: University of Pennsylvania Press. 


\section{Encountering Tourism}

Smith, V. L. 1977b. "Introduction." In Hosts and Guests: The Anthropology of Tourism, edited by V. L. Smith, 1-14. Philadelphia: University of Pennsylvania Press.

Smith, V. L. 1977c. "Eskimo Tourism: Micromodels and Marginal Men." In Hosts and Guests: The Anthropology of Tourism, edited by V. L. Smith, 51-70. Philadelphia: University of Pennsylvania Press.

Smith V. L. 1982. “Tourism to Greenland: Renewed Ethnicity?” Cultural Survival Quarterly 6 (3): 26-27.

Smith, V. L., and W. R. Eadington, eds. 1992. Tourism Alternatives: Potentials and Problems in the Development of Tourism. Chichester, UK: Wiley.

Speier, A. 2016. Fertility Holidays: IVF Tourism and the Reproduction of Whiteness. New York: New York University Press.

Srivastava, A., and K. Pandey. 2012. Anthropology and Tourism. New Delhi: Serials Publications.

Stasch, R., ed. 2015. Primitivist Tourism. Special issue, Ethnos 80 (4).

Stasch, R. 2017. “Tourism.” In The Cambridge Encyclopedia of Anthropology, edited by F. Stein, S. Lazar, M. Candea, H. Diemberger, J. Robbins, A. Sanchez, and R. Stasch, 114. Cambridge, UK: Cambridge University Press..

Stasch, R. 2019. "Primitivist Tourism and Anthropological Research: Awkward Relations." Journal of the Royal Anthropological Institute (n.s.) 25: 526-545.

Stout, N. 2014. After Love: Queer Intimacy and Erotic Economies in Post-Soviet Cuba. Durham, NC: Duke University Press.

Stronza, A. 2001. "Anthropology of Tourism: Forging New Ground for Ecotourism and Other Alternatives." Annual Review of Anthropology 30: 261-283.

Stronza, A. 2005. "Hosts and Hosts: The Anthropology of Community-Based Ecotourism in the Peruvian Amazon.” NAPA Bulletin 23: 170-190.

Swain, M. B. 1977. "Cuna Women and Ethnic Tourism.” In Hosts and Guests: The Anthropology of Tourism, edited by V. L. Smith, 71-82. Philadelphia: University of Pennsylvania Press.

Swain, M. B. ed. 1995. Gender in Tourism. Special issue, Annals of Tourism Research 22 (2).

Sylvain, R. 2005. "Disorderly Development: Globalization and the Idea of 'Culture' in the Kalahari." American Ethnologist 32 (3): 354-370.

Taylor, S. R. 2018. On Being Maya and Getting By: Heritage Politics and Community Development in Yucatán. Boulder: University Press of Colorado. 


\section{Encountering Tourism}

Theodossopoulos, D. 2016. Exoticisation Undressed: Ethnographic Nostalgia and Authenticity in Emberá Clothes. Manchester, UK: Manchester University Press.

Thompson, B. Y. 2019. "The Digital Nomad Lifestyle: (Remote) Work/Leisure Balance, Privilege, and Constructed Community." International Journal of the Sociology of Leisure 2 (1-2): 27-42.

Throop, J. C. 2014. "Morality, Friendship, and the Ethnographic Encounter." Suomen Antropologi 39 (1): 68-80.

Tonnaer, A. 2012. "Fifteen Minutes in Limbo: On the Intricacies of Rapport in Multi-Sited Fieldwork on Tourism." Qualitative Research 12 (5): 565-574.

Tornatore, J.-L. ed. 2019. Le patrimoine comme expérience. Implications anthropologiques. Paris: Editions de la maison des sciences de l'homme.

Tucker, H. 2003. Living with Tourism: Negotiating Identities in a Turkish Village. London: Routledge.

Tucker, H. 2009. "Recognizing Emotion and Its Postcolonial Potentialities: Discomfort and Shame in a Tourism Encounter in Turkey." Tourism Geographies 11 (4): 444-461.

Tucker, H., and J. Akama. 2009 "Tourism as Postcolonialism." In The SAGE Handbook of Tourism Studies, edited by T. Jamal and M. Robinson, 504-520. London: SAGE.

Tucker, H., and B. Boonabaana. 2012. "A Critical Analysis of Tourism, Gender and Poverty Reduction." Journal of Sustainable Tourism 20 (3): 437-455.

Turner, L., and J. Ash. 1975. The Golden Hordes. International Tourism and the Pleasure Periphery. London: Constable.

Turner, V., and E. Turner. 1978. Image and Pilgrimage in Christian Culture. New York: Columbia University Press.

Tzanelli, R. 2007. The Cinematic Tourist: Explorations in Globalisation, Culture and Resistance. London: Routledge.

Tzanelli, R. 2016. Thanatourism and Cinematic Representations of Risk: Screening the End of Tourism. London: Routledge.

Urbain, J.-D. 1991. L'Idiot du voyage: Histoires de tourists. Paris: Plon.

Urry, J. 1990. The Tourist Gaze. London: SAGE.

Urry, J. 2007. Mobilities. Cambridge, UK: Polity Press.

van den Berghe, P. 1980. "Tourism as Ethnic Relations: A Case Study form Cuzco, Peru." Ethnic and Racial Studies 3 (4): 376-392. 
van den Berghe, P. 1994. The Quest for the Other: Ethnic Tourism in San Cristóbal, Mexico. Seattle: University of Washington Press.

van der Duim, R., C. Ren, and G. T. Jóhannesson. 2012. Actor-Network Theory and Tourism: Ordering, Materiality and Multiplicity. London: Routledge.

van der Duim, R., C. Ren, and G. T. Jóhannesson. 2017. “ANT: A Decade of Interfering with Tourism". Annals of Tourism Research 64: 139-149.

Vastri, W. 2013. Volunteer Tourism in the Global South: Giving Back in Neoliberal Times. London: Routledge.

Vivanco, L. 2006. Green Encounters: Shaping and Contesting Environmentalism in Rural Costa Rica. Oxford: Berghahn Books.

Waldren, J. 1996. Insiders and Outsiders: Paradise and Reality in Mallorca. Oxford: Berghahn Books.

Wallace, T., ed. 2005. Tourism and Applied Anthropologists: Linking Theory and Practice. Special issue, NAPA Bulletin 23.

Wallace, T., and D. N. Diamente. 2005. "Keeping the People in the Parks: A Case Study from Guatemala." NAPA Bulletin 23: 191-218.

Walton, J. K. 2009. "Histories of Tourism." In The SAGE Handbook of Tourism Studies, edited by T. Jamal and M. Robinson, 115-129. London: SAGE.

Welz, G. 2015. European Products. Making and Unmaking Heritage in Cyprus. Oxford: Berghahn.

Werner, C. 2003. "The New Silk Road: Mediators and Tourism Developments in Central Asia." Ethnology 42 (2): 141-159.

White, L., and E. Frew, eds. 2013. Dark Tourism and Place Identity: Managing and Interpreting Dark Places. London: Routledge

Williams, B. 2018. The Pursuit of Happiness: Black Women, Diasporic Dreams, and the Politics of Emotional Transnationalism. Durham, NC: Duke University Press

Winter, T., P. Teo, and T. C. Chang. 2009. "Introduction: Rethinking Tourism in Asia.” In Asia on Tour: Exploring the Rise of Asian Tourism, edited by T. Winter, P. Teo, and T. C. Chang, 1-18. Oxford: Routledge.

Wood, R. 1980. "International Tourism and Cultural Change in Southeast Asia." Economic Development and Cultural Change 28 (3): 561-81.

World Tourism Organization; Center of Expertise Leisure, Tourism \& Hospitality; NHTV Breda University of Applied Sciences; and NHL Stenden University of Applied Sciences, 
eds. 2018. "Overtourism"?-Understanding and Managing Urban Tourism Growth beyond Perceptions, Executive Summary. Madrid: UNWTO.

World Tourism Organization; Center of Expertise Leisure, Tourism \& Hospitality; NHTV Breda University of Applied Sciences; and NHL Stenden University of Applied Sciences, eds. 2019. "Overtourism"?-Understanding and Managing Urban Tourism Growth beyond Perceptions, Volume 2: Case Studies, Executive Summary. Madrid: UNWTO.

Yamashita, S. ed. 1996. The Anthropology of Tourism. Tokyo: Shinyosha [in Japanese].

Yamashita, S. 2003. Bali and Beyond: Explorations in the Anthropology of Tourism. Oxford: Berghahn Books.

Yamashita, S. 2017. "Anthropologies of Tourism: A Project Toward a Global Anthropology.” American Anthropologist 119 (4): 744-747.

Zhang, X., and W. Li. 2008. Anthropology and Tourism. Nankai: Nankai University Press [in Chinese].

Zhu, Y. 2018. Heritage and Romantic Consumption in China. Amsterdam: Amsterdam University Press.

Zhu, Y., and C. Maags. 2020. Heritage Politics in China: The Power of the Past. London: Routledge.

Zhu, Y., L. Yin, and N. Graburn. 2017. “Domesticating Tourism Anthropology in China.” American Anthropologist 119 (4): 730-735.

Zorn, E., and L. C. Farthing. 2007. “Communitarian Tourism: Hosts and Mediators in Peru." Annals of Tourism Research 34 (3): 673-689.

\section{Notes:}

(1.) See Adler (1989), Lofgren (1999), and Walton (2009) for examples of elaborate and comprehensive reviews of the history and historiography of tourism.

(2.) It would be impossible to acknowledge the vast amount of international anthropological research currently being carried out on tourism, and the author's institutional and linguistic background and positionality bias his view of the field, which draws mainly on Euro-American, anglophone, and francophone sources. It is important to refer here to the range of monographs, edited volumes, special issues, and review articles on the anthropology of tourism that have been published in francophone academia (see Urbain 1991; Picard 1992; Amirou 1995; Michel 1998a, 2000; Le Menestrel 1999; Michaud 2001; Rauch 2002; Doquet and Le Menestrel 2006; Cauvin-Verner 2007; Doquet and Evrard 2008; Chabloz and Raout 2009; Boullosa, Demanget, and Dumoulin Kervran 2010; Saidi 2010; Cousin 2011; Cousin and Apchain 2016; Mancinelli 2017), in Spanish (see Santana Talavera 1997; Hernández-Ramírez 2006, 2015; Lagunas 2007; Nogués-Pedregal 2009; Fuller 


\section{Encountering Tourism}

2009; Oemichen Bazán 2013; Korstanje 2015; Palou Rubio and Mancinelli 2018a; Cañada and Murray 2019), in Portuguese (see Banducci and Barretto 2001; Graburn et al. 2009; Pereiro 2009; Pinto and Pereiro 2010; Sampaio 2013; Silva 2014; Pinto 2015; Pereiro and Fernandes 2015, 2018), and in Italian (see Simonicca 1997, 2004; Callari and Riccio 2001; Canestrini 2001, 2004; Aime 2005, 2007; Barberani 2006; Cipollari 2009). As recently stated by Salazar (2017), significant contributions must also be recognized from German (GATE 2005), Polish (Rancew-Sikora 2009; Owsianowska and Winiarski 2017; Banaszkiewicz and Owsianowska 2018), Japanese (Yamashita 1996, 2003), Indian (Srivastava and Pandey 2012), and Chinese (Peng 2004; Zhang and Li 2008) anthropologists, and the list is far from exhaustive. Stemming from academic centers in the United Kingdom and the United States, several review articles, monographs, and edited collections reviewing the field of the anthropology of tourism have appeared since the pioneering publication, in 1977, of Hosts and Guests: The Anthropology of Tourism (Smith 1977a, with its revised second edition published in 1989). These include Nash $(1981,1996)$, Graburn (1983a, 1983b), Crick (1989), Nash and Smith (1991), Selwyn (1994, 1996, 2007), Abram, Waldren, and Macleod (1997), Burns (1999), Chambers (2000), Stronza (2001), Franklin (2003), Gmelch (2004), Burns (2004), Scott and Selwyn (2010), Leite and Graburn (2009), Canosa et al. (2018), Stasch (2017), and Montero $(2018,2019)$.

(3.) A number of excellent publications reflect on the intersections and continuities between anthropology and tourism and between ethnographers and tourists. See, in particular, the writings of Crick (1985, 1995), Errington and Gewertz (1989), Bruner (1995, 1996), Kaspin (1997), Michel (1998b), Adams (2004), Simoni and McCabe (2008), Frohlick and Harrison (2008a), Mancinelli (2008), Nogués-Pedregal (2009), Tonnaer (2012), Salazar (2013), Sampaio, Simoni, and Isnart (2014), Martínez Mauri (2015), MacCarthy (2016), Theodossopoulos (2016), Pereiro and Fernandes (2018), Simoni (2018), and Stasch (2019).

(4.) See the edited collections of Badone and Roseman (2004) and Di Giovine and Picard (2015) for excellent overviews and more recent ethnographic case studies and anthropological reflections on the contemporary intersections of tourism and pilgrimage.

(5.) See, for instance, Amirou (1995), Lanfant, Allcock, and Bruner (1995), Selwyn (1996), Waldren (1996), Wood and Picard (1997), Abram, Waldren, and MacLeod (1997), Edensor (1998), Frey (1998), Ebron (2002), Harrison (2003), Richards and Wilson (2004), Bruner (2005), Nyiri (2006), Hannam and Ateljevic (2007), Basu (2007), Feldman (2008), Hannam and Diekmann (2010), Andrews (2011), Frohlick (2012), Picard and Robinson (2012), Salazar and Graburn (2014), Mostafanezhad and Hannam (2014), Leite (2017), Griffith and Marion (2017), Marshall (2017), and Williams (2018).

(6.) See, in particular, Chambers (1997a, 2000), Cheong and Miller (2000), Werner (2003), Zorn and Farthing (2007), and Feldman and Skinner (2018).

(7.) Among the recent anthropological work that is helping redress this bias, Cousin and Apchain (2016, 13-14) point to research on so-called "sharing platforms" and the accommodation industry (e.g., Couchsurfing, TripAdvisor, and AirBnB; see, in particular, the 


\section{Encountering Tourism}

edited volume of Picard and Buchberger [2013] and the work of Chareyron et al. [2014] and Oskam [2019]).

(8.) Note here the growing interest in exploring tourism's entanglements with media and technological innovations, including the audiovisual industries, the internet, and social media (see Tzanelli 2007, 2016; Dann 2012; Shao, Scarpino, and Gretzel 2012; Picard and Buchberger 2013; Kaplan and Shiff 2016; Beeton 2016; Ritter 2017; Lean, Staiff, and Waterton 2017; and Liestøl, Ritter, and Ibru 2019).

(9.) See Kinnaird and Hall (1994), Swain (1995), Pritchard et al. (2007), Andrews and Gupta (2010), Frohlick (2012), Figueroa-Domecq et al. (2015), Cole (2018), and Serrano Barquín, Rondríguez Muñoz, and Palmas Castrejón (2018) for a more recent valuation of gender-focused analyses of tourism.

(10.) See, for instance, the work of Boissevain (1996), Bowman (1996), Abram and Waldren (1997), Dahles and Bras (1999), Chambers (2000), Cheong and Miller (2000), Maoz (2006), and Simoni (2008).

(11.) Tourism-related processes of objectification and reshaping of "national", "cultural," and "ethnic" difference are subtly analyzed in the works of Picard $(1992,1996)$, van den Berghe (1994), Pemberton (1994), Adams (1998), Hitchcock (1998), Le Menestrel (1999), Lofgren (2001), Causey (2003), Little (2004), Franklin (2008), Comaroff and Comaroff (2009), Han and Graburn (2010), Babb (2011), Picard (2011), Asensio and Pérez Galán (2012), Brulotte (2012), Cousin (2011), Bunten (2015), MacCarthy (2016), Theodossopoulos (2016), Mancinelli (2017), Murray (2017), Taylor (2018), and Jacobsen (2018). See also the special issue on Primitivist Tourism, edited by Stasch (2015).

(12.) The book edited by Leite, Castañeda, and Adams (2019), The Ethnography of Tourism: Edward Bruner and Beyond, provides a timely collection of chapters that build and expand on Bruner's contribution, shedding new light on some of the key theories, themes, and concepts driving contemporary anthropological research on tourism, which the work of Bruner helped bring to the fore.

(13.) See, for instance, the monographs of Brennan (2004), Cabezas (2009), Jacobs (2010), Roux (2011), Frohlick (2012), Piscitelli (2013), Stout (2014), Daigle (2015), Meiu (2017), and Williams (2018).

(14.) See note 3 for literature dealing with the connections and continuities between anthropology and tourism.

(15.) For the website of the International Academy for the Study of Tourism.

(16.) For Critical Tourism Studies (CTS).

(17.) See, in particular, the publications of Hobsbawm and Ranger (1983), Linnekin (1983), and Handler and Linnekin (1984). 


\section{Encountering Tourism}

(18.) While far from exhaustive, it is worth mentioning here the monographs of Lowenthal (1996), Kirshenblatt-Gimblett (1998), Herzfeld (2004, 2009), Smith (2006), Breglia (2006), Adams (2006), Di Giovine (2009), Kaul (2009), Heinich (2009), Meskell (2012), Geismar (2013), MacDonald (2013), Silva (2013), Welz (2015), Munz (2016), Naef (2016), Grasseni (2016), Mancinelli (2017), Jacobsen (2018), Zhu (2018), De Cesari (2019), and Zhu and Maags (2020), and the edited collections of Demanget, Dumoulin Kervran, and Boullosa-Joly (2010), Insnart and Leblon (2012), Silva and Santos (2012), Hertz and Chappaz-Wirthner (2012), Isnart and Sonia (2014), Del Marmol, Morell, and Chalcraft (2014), Brulotte and Di Giovine (2014), Meskell (2015), Brumann and Berliner (2016), Anderson and Geismar (2017), Ploner and Naef (2017), De Lugan and Naef (2018), Larsen (2018), Meyer van de Port (2018), Hertz et al. (2018), Manjavacas (2018), Rodenberg and Wagenaar (2018), and Tornatore (2019).

(19.) For the website of the Association of Critical Heritage Studies.

(20.) A growing body of related scholarship sees anthropologists bringing to fruition the approach of actor-network theory to similarly unpack tourism's "translations" and "sociotechnical assemblages" (see the edited volumes of van der Duim, Ren, and Jóhannesson [2012], Jóhannesson, Ren, and van der Duim [2015], and the recent reassessment of van der Duim, Ren, and Jóhannesson [2017]).

(21.) Franklin's "touristification" effect draws attention to the many areas of life that, while not strictly speaking designed as tourism, have also been reordered by it, "from shopping to eating out, watching TV, surfing the net, marketing, branding and so on" (Franklin 2008, 36).

(22.) This is a view that finds fruitful parallels in Nogués-Pedregal's recent emphasis on approaching "tourism as a context" $(2019,228)$ and his theoretical model of the "conversion of place through tourism space” (2019, 233; see Nogués-Pedregal 2012).

(23.) The author draws on the remarks of one of the anonymous reviewers of the article, which he thanks for bringing his attention to these points.

(24.) Worth mentioning here is the growing reference to "overtourism" (World Tourism Organization; Center of Expertise Leisure, Tourism \& Hospitality; NHTV Breda University of Applied Sciences; and NHL Stenden University of Applied Sciences 2018, 2019), notably in an urban context but not only so (see Koens, Postma, and Papp 2018; Cheer, Milano, and Novelli 2019; and the range of case studies in Dodds and Butler 2019, and Milano, Novelli, and Cheer 2019).

(25.) See, for instance, the work of Morell (2009), Franquesa (2013), Hiernaux and González (2014), De Cesari and Herzfeld (2015), Gascón and Cañada (2016), Colomb and Novi (2017), Cocola-Gant (2018), Calvo and Ramos (2018), Sequera and Nofre (2018), as well as Pieroni and Naef's (2019) illustration of how processes of gentrification not only accompany tourism but may, in some cases, also become themselves objects of the tourist gaze. 


\section{Encountering Tourism}

\section{Valerio Simoni}

Graduate Institute, Geneva 